\title{
Pluralization, feminization and pitch accent in Djibouti Somali nouns
}

\author{
Nicola Lampitelli \\ Université François Rabelais de Tours and \\ Laboratoire Ligérien de Linguistique UMR 7270 CNRS, France \\ nicola.lampitelli@univ-tours.fr
}

\begin{abstract}
The goal of this paper is to present newly collected data of Djibouti Somali and show how it offers insight into the architecture of nouns. Djibouti Somali, as Standard Somali, is characterized by the presence of inflectional classes. Building on my own fieldwork material, I discuss both the empirical statements and the theoretical implications that emerge from the observation of three aspects of noun inflection: (1) pluralization strategies, (2) the position of pitch accent with respect to gender and (3) the opposition between Absolutive and Nominative case. In particular, the fact that Djibouti Somali uses mainly two suffixes to pluralize nouns, leads us to the hypothesis that the inflectional system of this variety consists of only two inflectional types. Basic non-derived nouns belong to what I call type A, whereas suffixed nouns belong to type B. This dichotomy is confirmed by the behavior of pitch accent with respect to both gender and syntactic case. Finally, I propose that the distinction between type $\mathrm{A}$ and type $\mathrm{B}$ can be accounted for, in the context of a formal analysis, by postulating the existence of a contrast between null vs.
\end{abstract}


overt nominalizer.

Keywords: Cushitic, Somali, noun inflection, pitch-accent, pluralization, feminine marker

\section{Introduction}

In this paper, I focus on the inflection of Somali nouns. I present newly collected data of Djibouti Somali and show how it offers insight into the architecture of noun structures. The data challenges the traditional view of Somali, which postulates the existence of noun classes.

The Somali language belongs to the lowland East-Cushitic group and is spoken in Somalia, Djibouti, Ethiopia and Kenya. The standard variety (henceforth Som) has emerged from Northern Somali dialects, spoken in Northern Somalia (also known as Somaliland, a de facto independent State), Djibouti and Ogaden (the southeastern portion of the Somali Regional State in Ethiopia); see Banti (2011) and Tosco (2012) for an overview of the situation of Somali language. Spoken Djibouti Somali (henceforth DJI) is therefore closely related to the standard variety. ${ }^{1}$ About $40 \%$ of the Djibouti population has DJI as mother tongue, although only French and Arabic benefit from "official language" status (see http://www.ethnologue.com/country/DJ/languages.)

Somali nouns are organized in inflectional classes. ${ }^{2}$ There is little agreement in the literature (Andrzejewski 1964, 1979; Banti 1988; Hyman 1981;

\footnotetext{
${ }^{1}$ To my knowledge, little to no attention has ever been paid to DJI (see Morin 1986, 2003 for some texts in Djibouti Somali). Those Djiboutians that speak Somali usually say they speak "Somali" even though with "some Djibouti accent" (Djibouti-ville is only $20 \mathrm{~km}$ away from the border with Somaliland). Abstracting away from socio-linguistic differences holding between speakers, I consider DJI as a locally-spoken variety of Northern Somali.

${ }^{2}$ As will become clear in Section 2, the term "noun class" must be understood as "inflectional nominal pattern".
} 
Lecarme 2002; Orwin 1995; Puglielli \& Siyaad 1984; Saeed 1993, 1999) on the exact number of classes: Hyman (1981) proposes only three distinct classes, whereas Andrzejewski (1979) counted up to ten of them. Yet, all the authors consistently propose to look at the following three parameters in order to determine the number of classes: (i) the position of pitch accent, (ii) the gender in the singular and in the plural and (iii) the way the plural is formed. Building on Godon (1998) and Lampitelli (2013), I claim that there are only two noun types. I will use empirical evidence from the DJI data in order to support this view and propose an analysis of nouns consistent with a syntactic approach to word formation, as advocated by Distributed Morphology (Halle \& Marantz 1993; Embick 2010).

The paper is organized as follows. In Section 2, I introduce the noun classes of Som. Section 3 focuses on the collected data as well as on the analysis of pluralization, feminization and pitch accent in DJI. In Section 4, I sketch out a novel analysis of the architecture of nouns in DJI. Section 5 is the conclusion.

\section{Noun inflection in Standard Somali}

The goal of this section is to present the complex inflectional system of Som nouns. This step will prove crucial for interpreting the data of DJI.

Andrzejewski $(1964,1979)$ noted that Somali has a prosodic system mixing tone features and stress. More precisely, he identified four tones: low, high, mid and falling. Falling tones occur only on long vowels and diphthongs. Each noun follows a particular accentual pattern, which consists of one or more accentual units, a fixed alternation of tone and stress. Hyman (1981) demonstrated that the phonetic differences heard in the realizations of tones can be reduced to a binary phonological opposition: high and low tone. He claimed that stress, 
which is associated either to the last or to the penultimate mora, is realized as high tone. In other words, Somali is a pitch-accent language. I follow Hyman's notation and will mark only the high tone with an acute accent on the stressed vowel: v́. Examples of distinctive pitch-accent contrasts are shown below: ${ }^{3}$

(1) Pitch-accent contrasts ${ }^{4}$
a. Iínan 'boy' vs. inán 'girl'
b. háan 'throat' vs. haán 'water vessel'
c. qáan 'young camel(s)' vs. qaán 'debt'

As mentioned in the introduction, the position of pitch-accent is one of the three parameters that are used to determine the inflectional pattern of a given noun. The second is the gender of the noun with respect to its number. Somali has two genders, masculine and feminine, as can be seen below: ${ }^{5}$
a. nín-ka
báa abees-ó
ark-aý
man-Det.M.Abs FM snake-F.Abs see-3sgM.Past.Red
'THE MAN saw a snake'
b. naág-ta báa abees-ó arag-t-aý
woman-Det.F.Abs FM snake-F.Abs see-3sgF-Past.Red
'THE WOMAN saw a snake'

\footnotetext{
${ }^{3}$ I adopt Standard Somali spelling. The following particular correspondences with the

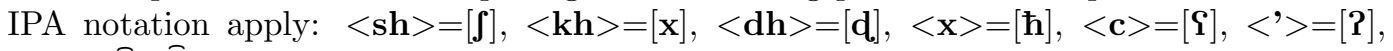
$<\mathbf{j}>=[\hat{\mathbf{t}} \mathbf{j} / \hat{\mathbf{d}} \mathbf{3}]$ and $<\mathbf{y}>=[\mathbf{j}]$.

${ }^{4}$ Tone is distinctive mainly in nouns and sometimes in verbs (for mood and/or tense) (ma) keenín 'he didn't bring it' vs. (ha) keénin 'don't bring it' (cf. Andrzejewski 1956). In addition, some words of different categories are distinguished by tone alone, e.g kú 'in, on' (Prep) vs. ku 'you' (Pro), lá 'with' (Prep) vs. la 'one' (Pro) (examples from Saeed 1993:23).

${ }^{5}$ In Somali, verbal agreement is reduced under certain conditions. More precisely, all persons have the $3 \mathrm{sgM}$ form except for $3 \mathrm{sgF}$ and $1 \mathrm{pl}$. In addition, reduced agreement forms take pitch-accent on the last syllable. The reduced agreement paradigm is referred to as the Reduced paradigm (Saeed 1993:72-74) and is used in two situations: (1) in relative subject clauses and (2) in main clauses, only when the subject is focused. More details on focused subjects can be found in the remainder of this section.
} 
In plural forms, however, some nouns change their gender. As we will see further in this section, the change of gender in plural forms depends on the noun class the noun belongs to.
a. nim-án-ka báa abees-ó ark-aý man-pl-Det.M.Abs FM snake-F.Abs see-3pl.Past.Red 'THE MEN saw a snake'
b. naag-á-ha báa abees-ó ark-aý woman-pl-Det.M.Abs FM snake-F.Abs see-3pl.Past.Red 'THE WOMEN saw a snake'

The form naag-á-ha in (3-b) corresponds to the bare plural naag-ó followed by the determiner ka: -ha is the surface form of underlying -ka, the $\mathrm{M}$ form of the determiner. ${ }^{6}$ Thus, the noun naag 'woman' is F in the singular (2-b) and $\mathrm{M}$ in the plural $(3-\mathrm{b})$.

This phenomenon, which I will refer to as gender polarity (Meinhof 1912; Lecarme 2002), occurs in both directions, $\mathrm{M}$ to $\mathrm{F}$ and $\mathrm{F}$ to $\mathrm{M}:^{7}$

\section{Gender polarity}
a. naág-/ta/ F sg. > naag-ó-/ka/ M pl. 'the woman'
b. ínan-/ka/ M sg. > inamm-ó-/ta/ F pl. 'the boy'
c. mádax-/ka/ M sg. > madáx-/ta/ F pl. 'the head'

Finally, the third parameter to determine the number of inflectional classes is the way in which plural is formed. Somali nouns pluralize according to five patterns involving three morphological strategies: suffixation ((5-a) to (5-c)),

\footnotetext{
${ }^{6}$ See Barillot (2002) for the analysis of the phonological processes involved in the allomorphy of determiners -ka (M) and -ta (F). In addition, note that the suffix -ó becomes -áwhen it is in a non-final position. The same happens to suffix -é: baré 'teacher' vs. baráha /bar+e+ka/ 'the teacher'. I will return to this later, in Section 4.

${ }^{7}$ See Maniscalco (2015) for a recent account of the gender system in Somali. In Maniscalco's analysis, gender is seen as the pairing between a singular and a plural form, similarly to what happens in typical noun class languages.
} 
reduplication (5-d) and prosodic shift (5-e).

(5) Pluralization patterns:

a. add the suffix -ó (attaches to both M and F nouns and can change the gender of the noun).

ex.: ínan M sg. > inamm-ó F pl. 'boy' and naág F sg. > naag-ó M pl. 'woman'.

b. add the suffix -yáal (attaches only to M nouns ending in -é and changes the gender of the noun).

ex.: baré M sg. > bara-yáal F pl. 'teacher'.

c. add the suffix -oyin (attaches only to F nouns ending in -ó and changes the gender of the noun).

ex.: shaqó F sg. > shaqo-óyin M pl. 'work'.

d. add -á- and a copy of the last consonant of the stem (it applies only to monosyllabic M nouns $)^{8}$

ex.: míis M sg. > miisás M pl. 'table'.

e. move the pitch-accent one vowel rightwards and change the gender of the noun (it applies only to M nouns).

ex.: mádax M sg. > madáx F pl. 'head'.

Putting together the position of pitch-accent, the gender polarity and the pluralization patterns in (5) corresponds roughly to the classification of nouns proposed by both Saeed $(1993,1999)$ and Orwin (1995).

In Saeed and Orwin's system, the nouns are classified according to their

\footnotetext{
${ }^{8}$ As pointed out by an anonymous reviewer, a few monosyllabic $\mathrm{F}$ nouns pluralize through reduplication of the last consonant of the stem: bud-/ta/ F sg. 'the tomb' > budad-/ka/ M pl. 'the tombs', qoor-/ta/ F sg. 'the neck' > qoorar-/ka/ M pl. 'the necks'. These nouns seem to be rare and, for this reason, I will not deal with them. As I show in the next section, a monosyllabic noun can select for patterns other than reduplication to express plurality.
} 
basic forms. The basic form of a noun corresponds to the absolutive case: there is a general consensus in taking Abs. as the default case (Banti 1988; Puglielli \& Siyaad 1984; Saeed 1993). The Abs. is used when a noun is either a focussed subject or a direct object (regardless whether it is focussed or not). ${ }^{9}$ In addition to the Abs. case, Somali has three other syntactic cases: nominative, genitive and vocative. The nominative case is used only for unfocussed subjects, whereas genitive serves to express possession. ${ }^{10}$ Vocative is used to denote the addressee. In this paper, I will deal mainly with absolutive and secondarily with nominative. Genitive and vocative will not be analyzed; see Frascarelli \& Puglielli (2005, 2007a,b) for the syntax of absolutive and Lampitelli (2013) for the morphological structure of absolutive, nominative and genitive.

Table 1 shows seven noun classes, divided into two main sets. The first set, labelled type A, contains those nouns that end in a consonant in the singular and bear either a final or a penultimate pitch-accent. ${ }^{11}$ The other set, labelled type B, contains those nouns ending in either -é or -ó, and bearing a final pitch-accent in the singular. Five classes (1 to 5 ) belong to type A, whereas only two, 6 and 7, form type B.

Type A is quite a heterogeneous group: class 1 includes all those nouns

\footnotetext{
${ }^{9}$ In Somali, an NP is focussed when it precedes either báa or ayáa, or when it is the last element in the wáxa construction. Cf. Saeed (1993:10-12; 233-235) and Orwin (1995:92-93; 159-161) for details. This means that word order depends on the position of focus/sentence particles. In declarative sentences containing a focused NP, word order is usually SOV. See Saeed (1993:215-244) and Gebert (1986) for further details.

${ }^{10}$ The Somali case system is more complex than it may seem at first sight. For instance, Nom. is used to express only a subset of possible subject configurations. In all other cases, Abs. is preferred (see Tosco 1994 and Andrzejewski 1984 for details). In addition, note that only the last item within the NP receives Nom. marking, be it a noun, a determiner, an adjective or a verb. All the other items, in turn, display Abs. case. This is what Saeed (1993) refers to as "premodifier form": nouns in premodifier form always display Abs. case. The reader is referred to Saeed (1993:144-147) and Le Gac (2001) for more details.

${ }^{11}$ As a matter of fact, a restricted group of nouns ending in -i (also spelled as $-\mathbf{y}$ when following a vowel) exist: mindí 'knife' F sg., ardéy 'student' M sg., béri 'day' M sg., etc... These nouns can belong to any of class 1 to 5 , but never to either class 6 or 7 .
} 
Table 1 - Noun classes, absolutive

\begin{tabular}{lllllll}
\hline class & type & singular & & plural & & \\
\hline & & bare N & gender & bare N & gender & \\
\hline 1 & $\mathrm{~A}$ & naág & $\mathrm{F}+$ & naagó & $\mathrm{M}$ & 'woman' \\
2 & $\mathrm{~A}$ & baabúur & $\mathrm{M}+$ & baabuurró & $\mathrm{F}$ & 'truck' \\
3 & $\mathrm{~A}$ & ílig & $\mathrm{M}$ & ilkó & $\mathrm{M}$ & 'tooth' \\
4 & $\mathrm{~A}$ & míis & $\mathrm{M}$ & miisás & $\mathrm{M}$ & 'table' \\
5 & $\mathrm{~A}$ & mádax & $\mathrm{M}$ & madáx & $\mathrm{F}$ & 'head' \\
& & & & & & \\
6 & $\mathrm{~B}$ & baré & $\mathrm{M}$ & barayáal & $\mathrm{F}$ & 'teacher' \\
7 & $\mathrm{~B}$ & shaqó & $\mathrm{F}$ & shaqoóyin & $\mathrm{M}$ & 'work' \\
\hline
\end{tabular}

whose singular form does not end in -o, and whose plural ends in -o and is masculine. These nouns are mostly feminine (this fact is indicated by $\mathrm{F}+$ in Table 1) in the singular and the pitch-accent is always on the final vowel. A small group of class 1 nouns behave differently with respect to the second vowel of their stem: this vowel alternates with zero in the plural, as in galáb sg. vs. galbó pl. 'afternoon' (see Godon 1998 and Barillot 2002 for more details.) Nouns in class 2 obey similar constraints: their singular form does not end in -e and their plural ends in -o and is feminine. Also, their singular is mostly masculine (this is marked as $\mathrm{M}+$ in Table 1) and the pitch-accent is always on the penultimate vowel. In addition, the last consonant of the stem is geminated when the plural suffix -o is added; if this consonant is a guttural, $\mathbf{j}$ or $\mathbf{s}$, the expected gemination is replaced by the cluster -Cy: daríiq sg. vs. dariiqyó pl. 'road'.

As mentioned, both class 1 and class 2 display exceptions with respect to the gender of the singular. According to both Saeed (1993) and Orwin (1995) some nouns belonging to class 1 are $\mathrm{M}$ and some nouns belonging to class 2 are F. I will not deal with these exceptional nouns: besides the fact that their exact number is unclear, their presence does not affect the proposals of this 
paper.

Classes 3 and 4 contain masculine nouns that do not change their gender in the plural (a few $\mathrm{F}$ nouns exist in class 4 , see footnote 8 above.) Both classes include nouns with a predictable syllabic structure. In class 3, the singular must be bisyllabic, and the two vowels are identical: $\mathrm{C}(\mathrm{V}) \mathrm{V}_{i} \mathrm{CV}_{i} \mathrm{C}$. The pitchaccent is on the penultimate vowel. The plural is formed by suffixation of -o. The second vowel undergoes syncope, making the syllabic structure of these plurals as follows: C(V)VCCo. In comparison, class 4 contains monosyllabic nouns, consisting of a closed syllable with either a short or a long vowel: $\mathrm{C}(\mathrm{V}) \mathrm{VC}$. When the vowel is long, the pitch-accent is penultimate. Their plural is formed by inserting the vowel /a/ at the end of the stem; then a copy of the last consonant of the stem is added to its right.

The heterogenous status of classes 1 to 5 is confirmed by class 5 . Nouns belonging to it have 1 to 3 syllables, bear a penultimate pitch-accent and are all masculine in the singular. Interestingly, their plural is formed by changing the gender (from $\mathrm{M}$ into $\mathrm{F}$ ) and by moving the pitch-accent one vowel rightward. In other words, no segmental suffix is used to pluralize these nouns. An anonymous reviewer raises the question of whether the fact of changing the gender and the pitch-accent shift belong to the same process or they are two separate morphophonological mechanisms. In Lampitelli (2013), I claim that the pitch-accent marks the syntactic case and follow Godon (1998) in arguing for a fixed position of the pitch-accent in the Abs. case. According to this analysis, the gender changes because the pitch-accent moves one vowel rightward in the plural.

Type B consists of classes 6 and 7 . Both classes contain only those nouns that end in either -e or -o in the singular: the former includes M nouns ending in -e (cf. baré 'teacher'), whereas the latter includes F nouns ending in -o 
(cf. shaqó 'work'). ${ }^{12}$ Both have a specific plural suffix which is added to the singular form (cf. barayáal 'teachers' and shaqoóyin 'works'). In addition, the plural forms change the gender of the singular.

The vowels -e and -o behave as suffixes. In fact, they both display fixed gender and trigger a specific suffix in the plural. Although the plural forms exhibit polarity, gender is always predictable in type B nouns. In addition, these suffixes may be used to create a noun out of a verbal root, as in the examples below:
a. baré 'teacher' vs. bar 'to teach'
b. furé 'key' vs. fur 'to open'
c. sheekó 'story' vs. sheeg 'to tell'13
d. hurdó 'sleep' vs. hurud 'to sleep'14

Other type B nouns, in contrast, are built on roots that are not found in isolation: aabbé 'father', *aabb; hooyó 'mother', *hooy; dabó 'tail, back part', *dab (The root dáb is found in nouns, and means 'fire' M class 4.) Following Puglielli \& Siyaad (1984) and Lecarme (2002), I assume that all type B nouns are derived precisely because they are suffixed. ${ }^{15}$

\footnotetext{
${ }^{12}$ Type B recalls Andrzejewski's (1964:33-34) fifth declension. In his dissertation, Andrzejewski classifies all masculine singular nouns ending in -e and all feminine singular nouns ending in -o within a single group.

$13 / \mathbf{k} /$ is realized as $[\mathbf{k}]$ (spelled as $\mathbf{g}$ ) in final codas and as $\left[\mathbf{k}^{\mathbf{h}}\right]$ (spelled as $\mathbf{k}$ ) elsewhere. See Armstrong (1934) for details.

${ }^{14}$ The root is /hurd/, the second $-\mathbf{u}$ appears in the verb to avoid final CC clusters, see Barillot (2002) for an analysis of /CVCC/ verbs in Somali.

${ }^{15}$ Another anonymous reviewer raises the question of whether Somali plural is inflectional or derivational. The behavior of Somali plural looks inflectional if one considers the following two features. First, suffix -o (classes 1,2 and 3) does not bear inherent gender: o-plurals can be either M naagó ‘women' or F babuurró ‘trucks'. Second, gender plurality is bidirectional $(\mathrm{M}>\mathrm{F}$ and $\mathrm{F}>\mathrm{M})$, whereas pitch-accent shift goes only from left to right, that is from $\mathrm{M}$ to F (class 5): búug M 'book' $\rightarrow$ buúg F 'books', naág M 'woman' * $\rightarrow$ *naág M 'women' is ungrammatical. Classes 6 and 7 , in turn, seem derivational to the extent that suffixes -yáal and -óyin attach to suffixed singular forms and impose their own gender. I return to this discussion at the end of the paper, in Section 4 where I present an analysis of noun classes in the light of the DJI data.
} 
To conclude, I take type B nouns to be complex items derived by attaching a vocalic suffix to a consonant-final root. In contrast, type $\mathrm{A}$ contains those nouns that are basic and non-derived (=unsuffixed). The structural difference between type A and type B is formalized in Section 4.

In the next section, I present the data collected in Djibouti and focus on the analysis of pluralization, feminization and pitch-accent in DJI.

\section{Noun inflection in Djibouti Somali}

This section is organized in four subsections. In the first subsection, 3.1, I introduce the data collected in Djibouti and a few general facts regarding fieldwork activity. In subsection 3.2, I explore the strategies of pluralization in DJI. In subsection 3.3, I analyze a few cases where the position of pitchaccent is distinctive with respect to the gender. Finally, subsection 3.4 shows the behavior of pitch-accent with respect to the opposition between Abs. and Nom.

\subsection{Djibouti Somali}

The data was collected in Djibouti, in June 2012, as part of the fieldwork activity conducted by the author in collaboration with the Université de Djibouti.

Fifteen people were interviewed: they are all born in Djibouti, either in the capital city Djibouti-ville or in the neighboring villages. Informants are 16 to 31 years old, except one whose age is unknown. Eleven informants are male, four are female. All the informants are literate, holding either the Middle School Certificate (Brevet) or the High School Certificate (Baccalauréat). The usual teaching language is French.

The data has been collected in the following two manners: 

a. Transcriptions during the interviews
b. Recording of the informants

The corpus contains two kinds of items:

(8) a. Noun entries (the form of both the singular and the plural of a noun)

b. Sample sentences

Appendix A includes the complete list of the noun entries; each singular form is accompanied with the corresponding plural form(s). The sentences used as sample, in turn, are given within the text when needed.

The data will be used to study the following three aspects of noun inflection:

(9) a. the strategies of pluralization

b. the position of pitch-accent with respect to gender

c. the opposition absolutive vs. nominative

Section 3.2 focuses on point (9-a): it is shown that, in DJI, pluralization involves mainly two suffixes (contrarily to what has been shown in Som). Section 3.3 presents the discussion involving the expression of gender in DJI (point (9-b) above) and, finally, point (9-c) is dealt with in Section 3.4 where pitch contours are displayed showing that two kinds of opposition absolutive vs. nominative arise. 


\subsection{The plural marker in Dji}

The corpus contains a sample of 150 noun entries (see Appendix A). This sample has been established on the basis of the examples of Som provided by Orwin (1995), Saeed (1993) and Puglielli \& Siyaad (1984). As stated in the introduction, DJI is a locally-spoken variety of Somali: for this reason, I adopt the Som noun classes as a starting point for collecting DJI data. Appendix A is organized according to this principle: each noun is allotted one (or more) noun classes depending on what one expects to find in Som. Plural forms, in turn, correspond to those produced by DJI speakers during the interviews.

The data were gathered as follows. The author pronounced the singular form of each noun in Somali (in a random order) and each informant proposed one or more possible plural forms. Showing the written form of the nouns was avoided: Somali speakers in Djibouti usually do not know the official spelling of their language. As one anonymous reviewer points out, future research should test which plural form is listed first by each native speaker. This fact could prove useful in determining which forms are default in DJI.

The results of this inquiry clearly show that, in DJI, there is a strong tendency to form the plural in the following two ways:

(10) Strategies of pluralization in DJI
a. suffixation of -ó
b. suffixation of -yáal

The suffix -ó, which in Som is used to pluralize classes 1, 2 and 3 (cf. Table 1 above), can also be used to pluralize nouns belonging to classes 4 and 5 . In a similar way, the suffix -yáal, which in Som is found only as the plural of class 6, applies to a larger range of classes, namely classes $2,3,4,5,6$ and 7 . In 
addition, there are cases where -yáal is used to pluralize class 1 nouns, too.

This situation is schematized below:

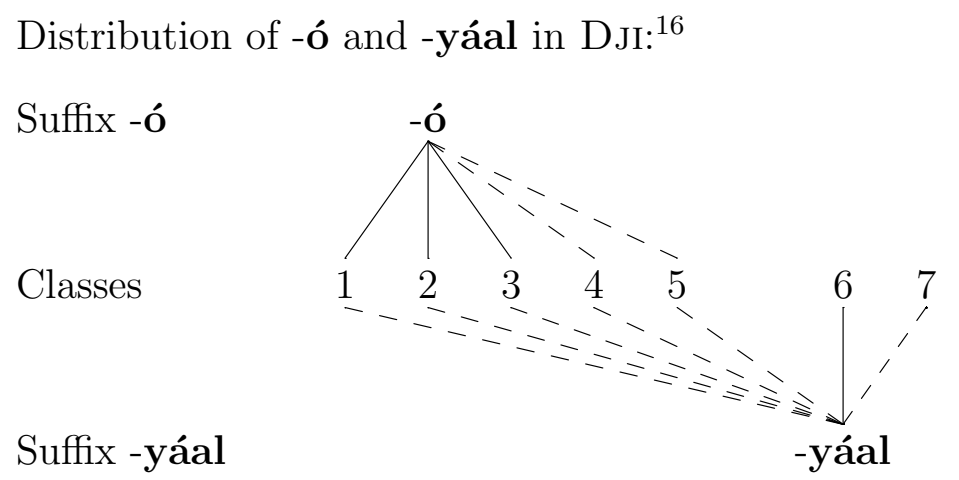

The continuous lines represent the distribution of each suffix found both in Som and in DJI, whereas the dotted lines represent the distribution of these suffixes found only in DJI.

The situation depicted in (11) suggests that we are dealing with a simplification of the complexity of Som noun morphology. More specifically, classes 1 to 5 (labelled type A in Table 1 above) accept two suffixes in DJI, contrary to the situation found in Som where each class is defined according to a number of morphophonological constraints (gender of the singular, syllable structure, position of pitch-accent, presence/absence of particular suffixes, etc...) As for type B, class 6 remains as in Som; class 7 accepts both the standard suffix -oyin and the suffix -yáal.

Table 2 shows the respective occurrences of -ó and -yáal across each class. The data in Table 2 read as follows. Take, for instance, class 2. The corpus contains 59 items belonging to this class. Among these items, 55 can be

\footnotetext{
${ }^{16}$ The distribution of -yaal is strikingly similar to a cognate suffix -yal appearing in Maay, spoken in Lower Jubba in Southern Somalia. In this language, vowel-final nouns pluralize exclusively with a -yal suffix, whereas consonant-final nouns have three possible plural forms: (1) one using an -o suffix, (2) one using the same -yal as for vowel-final nouns and, (3), one using both suffixes. The following example illustrates this situation: af 'mouth' vs. af-o, af-yal, af-o-yal 'mouths'. I thank an anonymous reviewer for bringing this fact to my attention. See Paster (2010:179-182) for more data and analyses.
} 
pluralized with suffix -ó (this number represents $93 \%$ of total occurrences of class 2 nouns), whereas 46 items can be pluralized with suffix -yáal (that is $78 \%$ of class 2 nouns). Finally, marginal plurals are listed in the last column: 2 items can be pluralized through reduplication, 4 display irregular plural forms and 2 trigger pitch-accent shift. A given noun can adopt more than one plural strategy: this explains why the total amount of plural forms exceeds the number of class 2 nouns. (Recall that the main goal of this paper is to show that new pluralization patterns arise in DJI.) The complete information about each noun is provided in Appendix A. Finer statistical investigations will have to establish a larger representative sample of nouns in order to study the corresponding pluralization patterns and their frequencies of realization for each informant.

Table 2 - Occurrences of suffixes -ó and -yáal

\begin{tabular}{l|l|ll|ll|l} 
class & \# items & -ó & $\%$ & -yáal & $\%$ & other plurals \\
\hline 1 & 37 & 34 & $92 \%$ & 9 & $24 \%$ & 6 (rdp), 1 (irr) \\
2 & 59 & 55 & $93 \%$ & 46 & $78 \%$ & 2 (rdp), 4 (irr), 2 (shift) \\
3 & 7 & 7 & $100 \%$ & 4 & $57 \%$ & - \\
4 & 26 & 9 & $34 \%$ & 12 & $46 \%$ & 25 (rdp), 2 (oyin) \\
5 & 7 & 4 & $57 \%$ & 7 & $100 \%$ & 7 (shift), 1 (rdp) \\
\hline 6 & 6 & - & & 6 & $100 \%$ & 3 (-oyin) \\
7 & 11 & - & & 5 & $45 \%$ & 11 (-oyin) \\
\hline total & $153^{17}$ & 109 & $71 \%$ & 89 & $58 \%$ &
\end{tabular}

It is worth noting the following facts. First, 46 nouns, out of 59 belonging to class 2 (thus M in the singular), take the suffix -yáal (in addition to regular -ó). Second, only 9 nouns, out of 34 belonging to class 1 (thus $F$ in the singular), pluralize with -yáal in addition to regular -ó. Third, class 3 (M in the singular) has 4 cases out of 7 which take -yáal in the plural. Recall that class 3 nouns do not change their gender in the plural. As for classes 4

\footnotetext{
${ }^{17}$ This number corresponds to 150 distinct nouns. Three of them have been counted twice: géed M 1/3, mádax M 2/5 and maalín $\mathrm{F} / \mathrm{M} 1 / 2$ as they belong to two distinct classes. Irregular plurals are given in Appendix A when known by the informants.
} 
and 5, in Som, neither of these classes pluralizes using suffixation; in DJI, in turn, both -ó and -yáal can be used (with stronger preference for the latter). Finally, note that -ó does not work with type B nouns. The suffix -yáal, on the other hand, does apply to both class 6 (100\% of the occurrences) and class 7 (45\% of occurrences) nouns.

Interestingly and not surprisingly, loans can be pluralized with both -ó and -yáal, as the following example shows:

(12) The plural in loans:

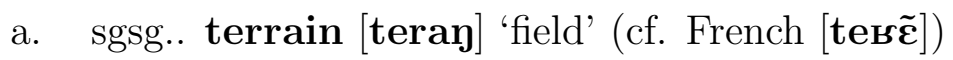
b. pl. 1: terranó
c. pl. 2: terranyáal

Recent loans are all M: ordinatéer(-ka) 'computer', boortáabl(-ka) 'cell phone', skóol(-ka) 'school', telfísyon(-ka) 'TV', etc. In Som, some older loans, such as búug M cl 2/4 'book' and boostó F cl 7 'post office' are fully integrated in the system and take regular plurals. Some loans from Arabic, in turn, maintain the original broken plural: márkab M 'ship' > maraakiíb F 'ships', kúrsi M 'chair' > kuraasí F 'chairs', qálin M 'pen' > qalmaán F 'pens'. In some cases, two possible plural forms exist: regular kursiyó F 'chairs' and qalimmó F 'pens' are attested and confirmed by the informants (see Appendix A). For more details on loans in Som, see Mioni (1988); Saeed (1999); Zaborski (1967).

As for Som regular plurals of class 4 and class 5 (reduplication and pitchaccent shift), these strategies are quite marginally used in DJI:

(13) Marginally-used strategies of pluralization:

a. reduplication of the last $\mathrm{C}$ of the stem + insertion of $/ \mathbf{a} /$; 
b. Pitch-accent shift

In Som, the strategy (13-a) targets exclusively monosyllabic M nouns, such as miís 'table' (class 4). The DJI data show that the constraint on monosyllabicity is not enough to enforce reduplication to pluralize a noun. In fact, as Table 2 shows, there are cases of reduplicated plurals occurring in classes other than class 4 (6 in class 1; 2 in class 2 and 1 in class 5 ). As for (13-b), in turn, only the M nouns can be pluralized by moving the pitch-accent one vowel rightwards: mádax 'head' (class 5). For instance, the overwhelming majority of the informants (12 out of 15) did not propose madáx 'heads' as the corresponding plural of mádax 'head': rather, they proposed either madaxyó or madaxyáal. The form madáx 'heads', however, has been recognized as a plural when mentioned by the author. As can be seen in Table 2, pitch-accent shift is regressing: 7 nouns out of 7 from class 5 have two distinct ways to pluralize: (i) pitch-accent shift and (ii) suffix -yáal.

Finally, we have to discuss the status of the suffix -oyin. In Som, this suffix is used to pluralize exclusively those nouns ending in -ó in the singular (they belong to class 7 and are $\mathrm{F}$ in the singular). In DJI the situation is as follows. We find, as expected, -oyin in class 7 (although in competition with -yáal in 5 cases out of 11). In addition, three nouns pluralize with this suffix in class 6 (also in competition with -yáal) and, finally, two instances of -oyin are found in class 4 (that of reduplicated plurals).

Table 3 recapitulates the comparison between plurals in Som and in DJI.

Compared to the rich inflectional inventory of Som, DJI has generalized the use of two suffixes: -ó and -yáal. This fact is especially interesting in light of the observation that Som exhibits variation in the pluralization patterns.

\footnotetext{
${ }^{18}$ Suffix -yáal cannot attach to naág.
} 
Table 3 - Som and DJI plurals

\begin{tabular}{llllll} 
cl & $\begin{array}{l}\text { Som/DJI } \\
\text { singular }\end{array}$ & gen & $\begin{array}{l}\text { SoM } \\
\text { plural }\end{array}$ & $\begin{array}{l}\text { DJI } \\
\text { plural }\end{array}$ \\
\hline 1 & gabádh & F & gabdhó & gabdhó, gabdhyáal & \\
2 & baabúur & M & baabuurró & baabuurró, baabuuryáal & 'girl' \\
3 & ílig & M & ilkó & ilkó, iligyáal & 'tooth' \\
4 & míis & M & miisás & miisó, miisyáal, miisás & 'table' \\
5 & mádax & M & madáx & madaxyó, madaxyáal, madáx & 'head' \\
\hline 6 & baré & M & barayáal & barayáal & 'teacher' \\
7 & shaqó & F & shaqoóyin & shaqoóyin, shaqayáal & 'work' \\
\hline
\end{tabular}

Godon (1998) reports that her informant accepts two plurals for most M nouns belonging to either class 2 or class 5: díbi M cl 5 'bull' > dibí F pl. (pitchaccent shift), dibiyó F pl. (suffixation of -ó) 'bulls'. Saeed $(1993,1999)$ and Orwin (1995) claim that some nouns display more than a plural form, but no complete work on this topic has been done on Som to my knowledge. This situation encourages further study about the status of the noun classes in the language: we are dealing with an ongoing process of simplification of noun inflection in DJI, although marginal pluralization patterns are still in use (as Table 2 shows.) I will turn to this topic later, in Section 4, where I discuss the theoretical implications of the data presented so far.

In the following subsection, I explore the relation between gender and pitchaccent.

\subsection{The position of pitch-accent with respect to gender}

Since Hyman (1981), there is consensus about the fact that pitch-accent occupies either the last vocalic position or the penultimate one. Hyman managed to reduce to a binary contrast what Andrzejewski $(1956,1964,1979)$ described as a very complex system of interactions between stress and tone. More recently, Le Gac (2001:110-125 and 2003:53-54) observed that, in Som, the contrast 
between the following pairs of nouns is maintained:

(14) Pitch accent contrasts (absolutive)
a. ínan M 'boy' vs. inán F 'girl'
b. béer M 'liver' vs. beér F 'garden'

Hyman's analysis has the advantage of predicting the correlation between gender and the position of pitch-accent. Masculine nouns have penultimate pitchaccent, whereas feminine nouns display final pitch-accent.

The DJI data confirms the hypothesis on the correlation between the position of pitch-accent and the gender of the noun. The phonetic analysis of Djibouti-collected recordings reveals that the pitch is found at the expected positions when the nouns are considered in isolation. This generalization, however, holds true only for type A. In fact, as Le Gac (2001) has already noticed, type B nouns behave in a different way. Both class 6 and class 7 display final pitch-accent in the Abs. case, thus neutralizing the distinction of gender.

In this section, I show the pitch tracks and highlight the pitch-accent contrasts between masculine and feminine nouns. I start with the well-known pair ínan M sg. Abs. 'boy'/inán 'girl' F sg. Abs.; then, I show two pairs containing monosyllabic nouns with a long vowel. These pairs are: naág F sg. Abs. 'woman'/míis M sg. Abs. 'table' and gées M sg. Abs. 'horn'/heés M sg. Abs. 'song' (type A). Finally, I show the pair baré M sg. Abs. 'teacher'/shaqó F sg. Abs. 'work', where two suffixed nouns are compared (type B). The examples are selected from the recordings of a unique speaker, a 30 year-old male born in Dikhil (Southern Djibouti).

As for type A, the opposition between ínan M sg. Abs. 'boy' and inán F sg. Abs. 'girl' is confirmed by all the informants. Figure 1 shows M ínan, 
whereas Figure 2 shows the F counterpart inán. The contrast between initial and final pitch-accent is strikingly clear: in Figure 1 pitch-accent is initial, whereas in Figure 2 pitch-accent is final.

Figure 1 - ínan M sg. Abs. 'boy'
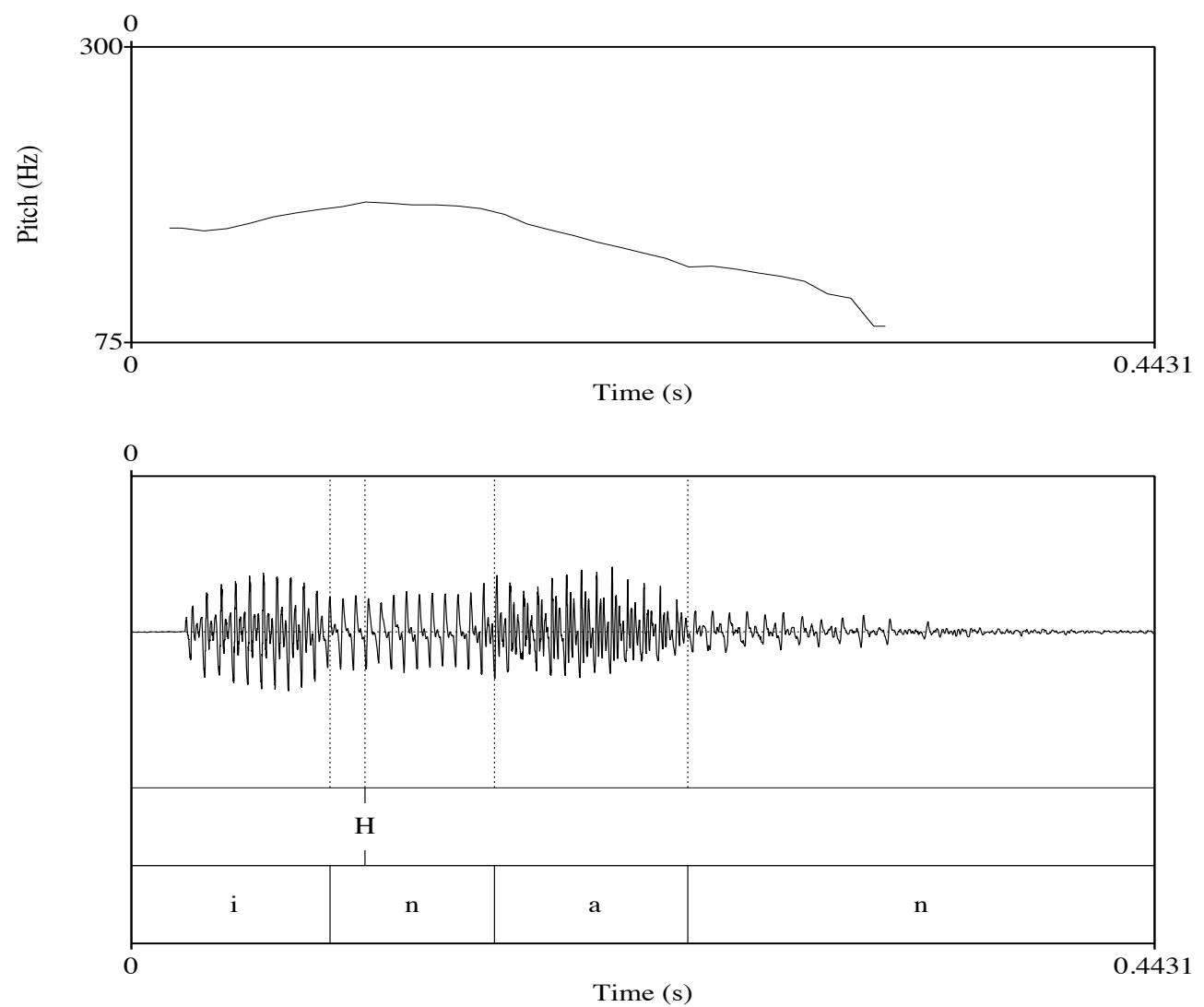

The situation is more complex in the monosyllabic nouns. The informants that I interviewed do not generally recognize minimal pairs based on monosyllabic nouns, except for a few cases. For instance, the contrast between néef $\mathrm{M}$ sg. Abs. 'pet' and neéf F sg. Abs. 'breath' is known to 6 informants. While recording these pairs, however, I could notice that the informants weren't spontaneous and they sometimes hesitated. Because of the weak distinctive status these nouns have in DJI, I decided not to include such minimal pairs in my discussion.

Despite this fact, pitch contrasts are distinguished in pairs such as míis 
Figure 2 - inán F sg. Abs. 'girl'
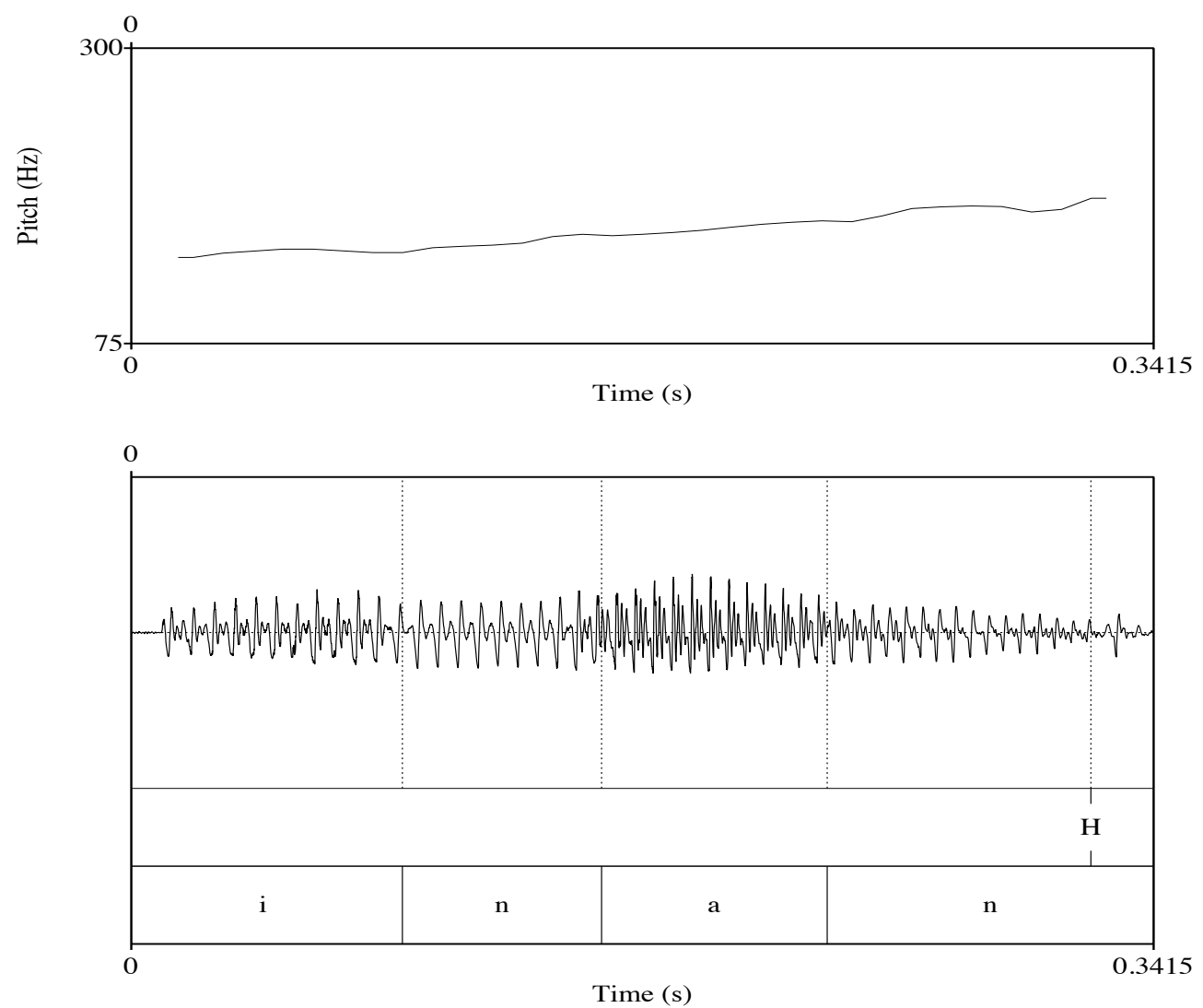

M sg. Abs. 'table'/náag F sg. Abs. 'woman' and gées M sg. Abs. 'horn'/ heés F sg. Abs. 'song'. In the former pair, the nouns share only the syllabic structure CVVC; in the latter they share the syllabic structure (again, CVVC), the vowel /e/ and the final consonant /s/. Figures 3 to 6 show these contrasts.

As for type B nouns, there is no contrast with respect to gender. In fact, both baré M sg. Abs. 'teacher' and shaqó F sg. Abs. 'work' display final pitch-accent. This means that suffixes -e and -o, respectively $M$ and F, bear high tone. In other words, whilst pitch-accent position correlates with gender in non-derived nouns (type A), it does not to do so in derived suffixed nouns (type B).

The F0 curves in Figures 7 and 8 present unequivocal proof confirming the neutralization of the position of pitch-accent in type B. Note that, in my 
Figure 3 - míis M sg. Abs. 'table'
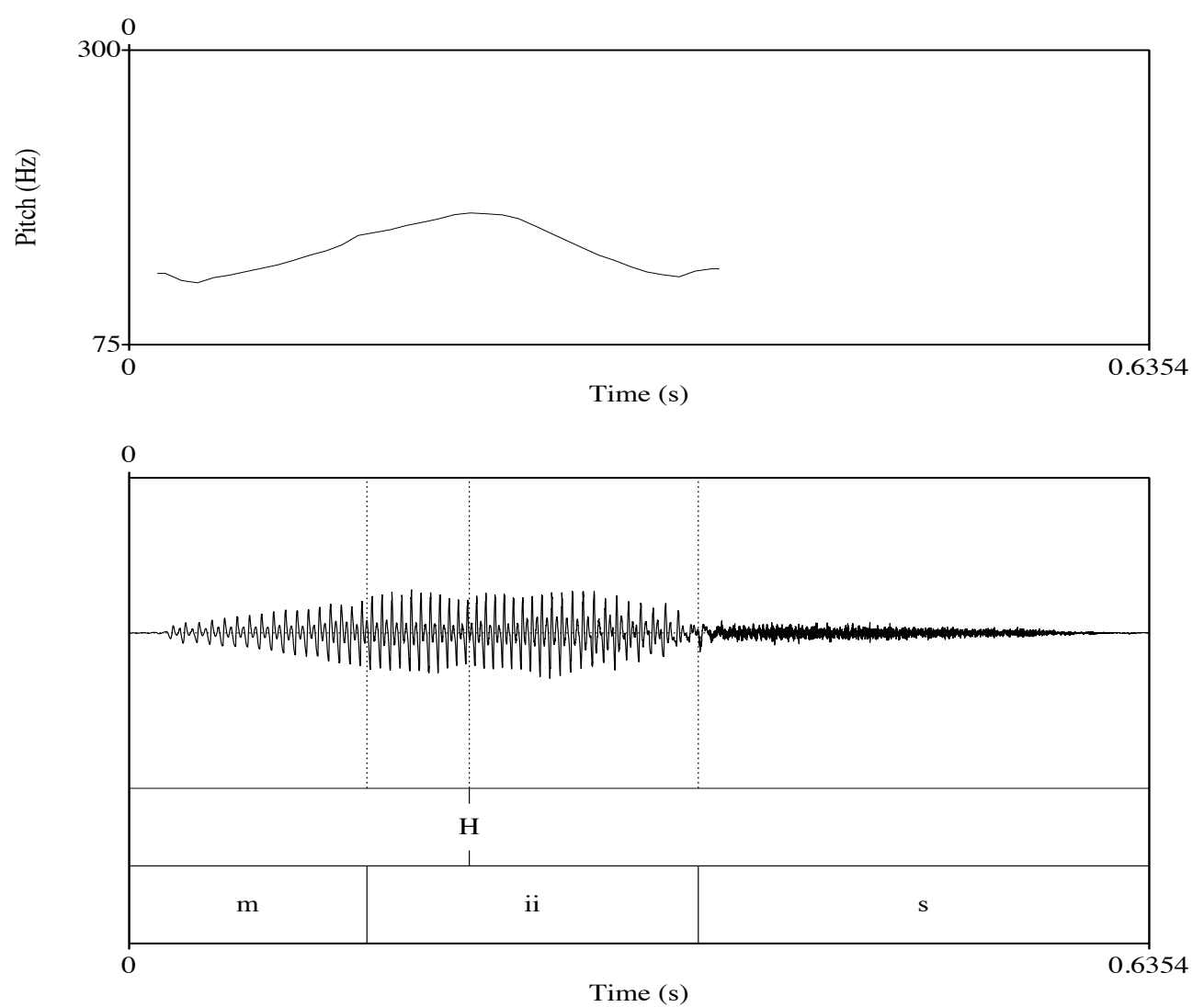
Figure 4 - naág F sg. Abs. 'woman'
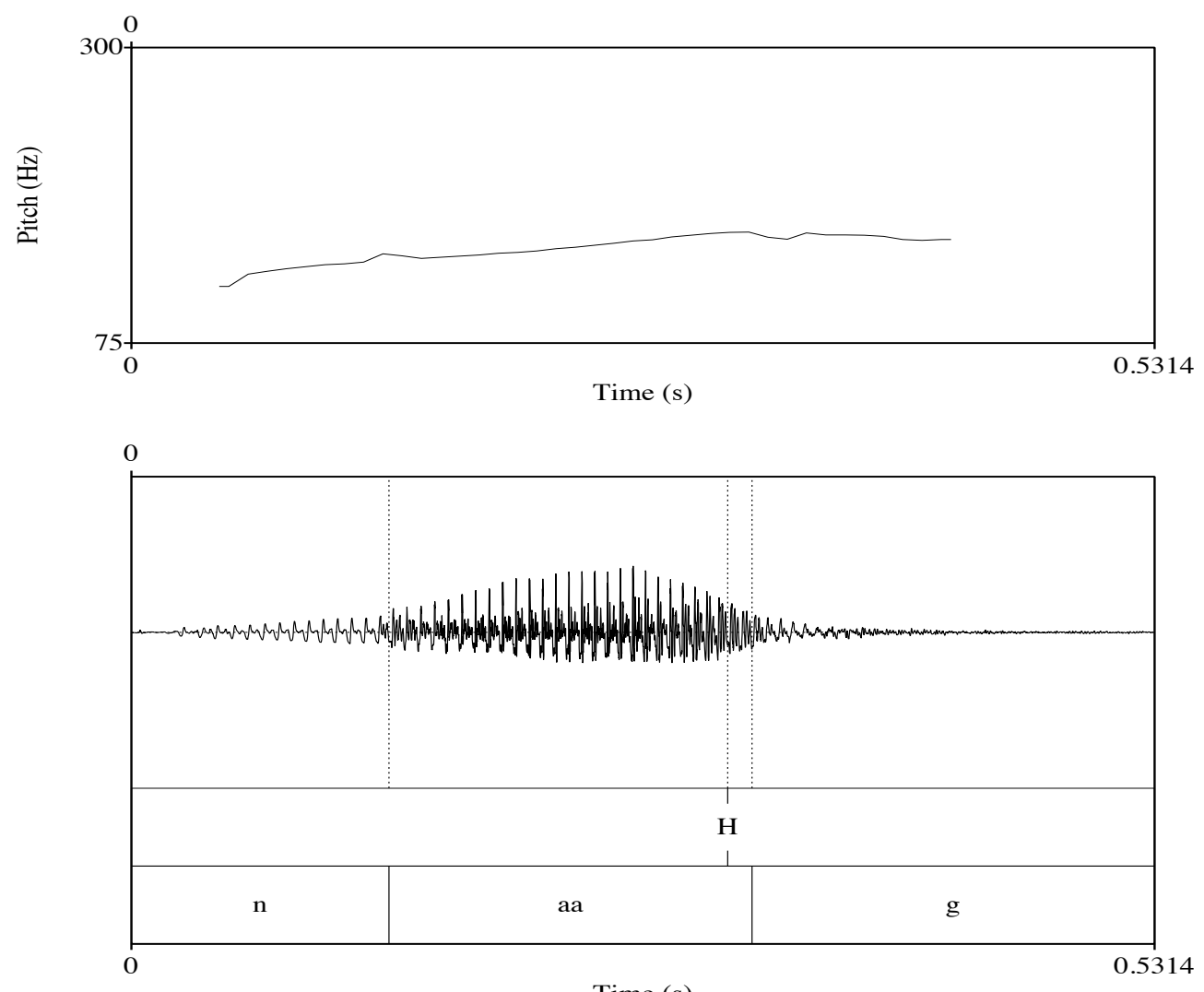
Figure 5 - gées M sg. Abs. 'horn'
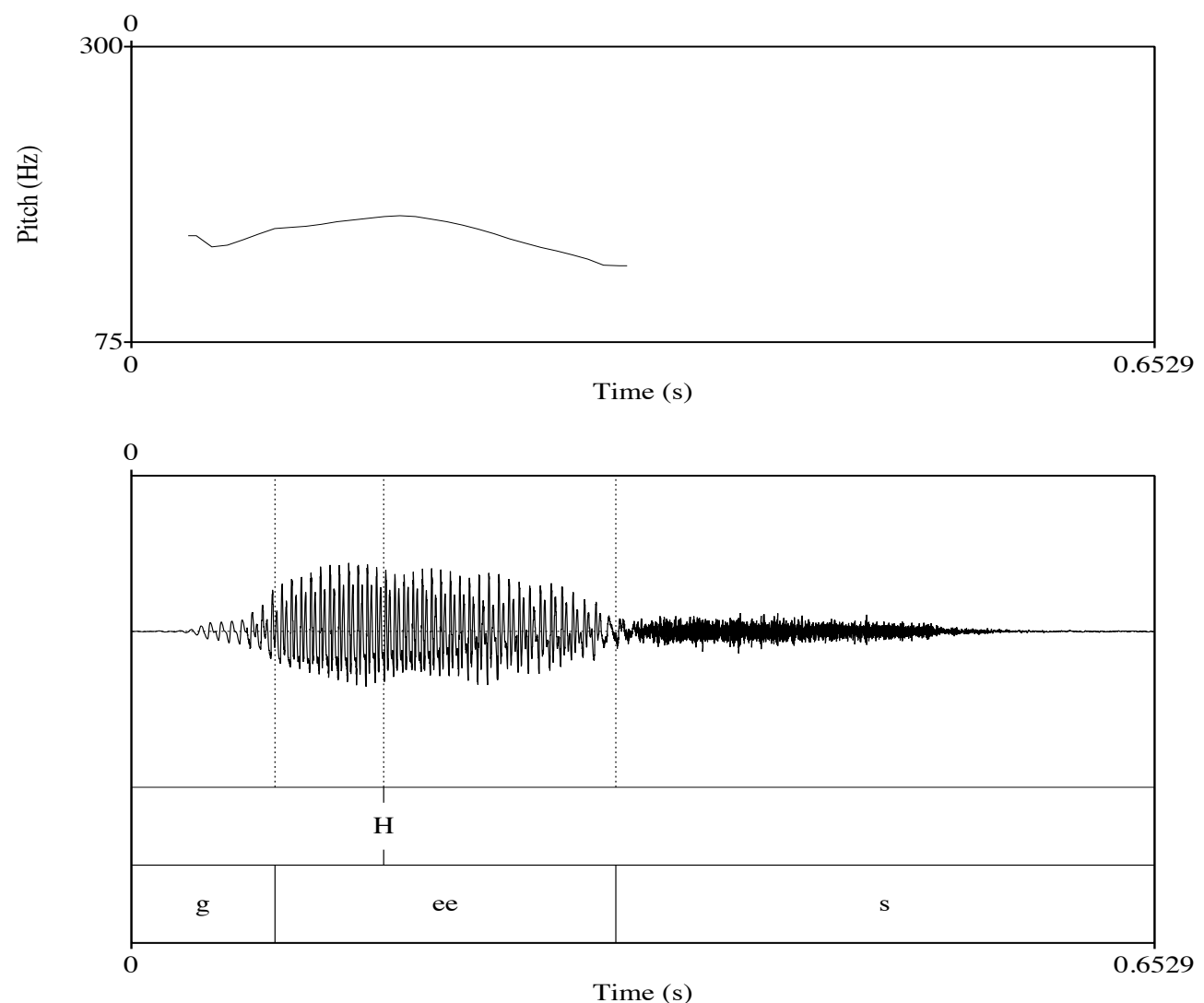
Figure 6 - heés F sg. Abs. 'song'
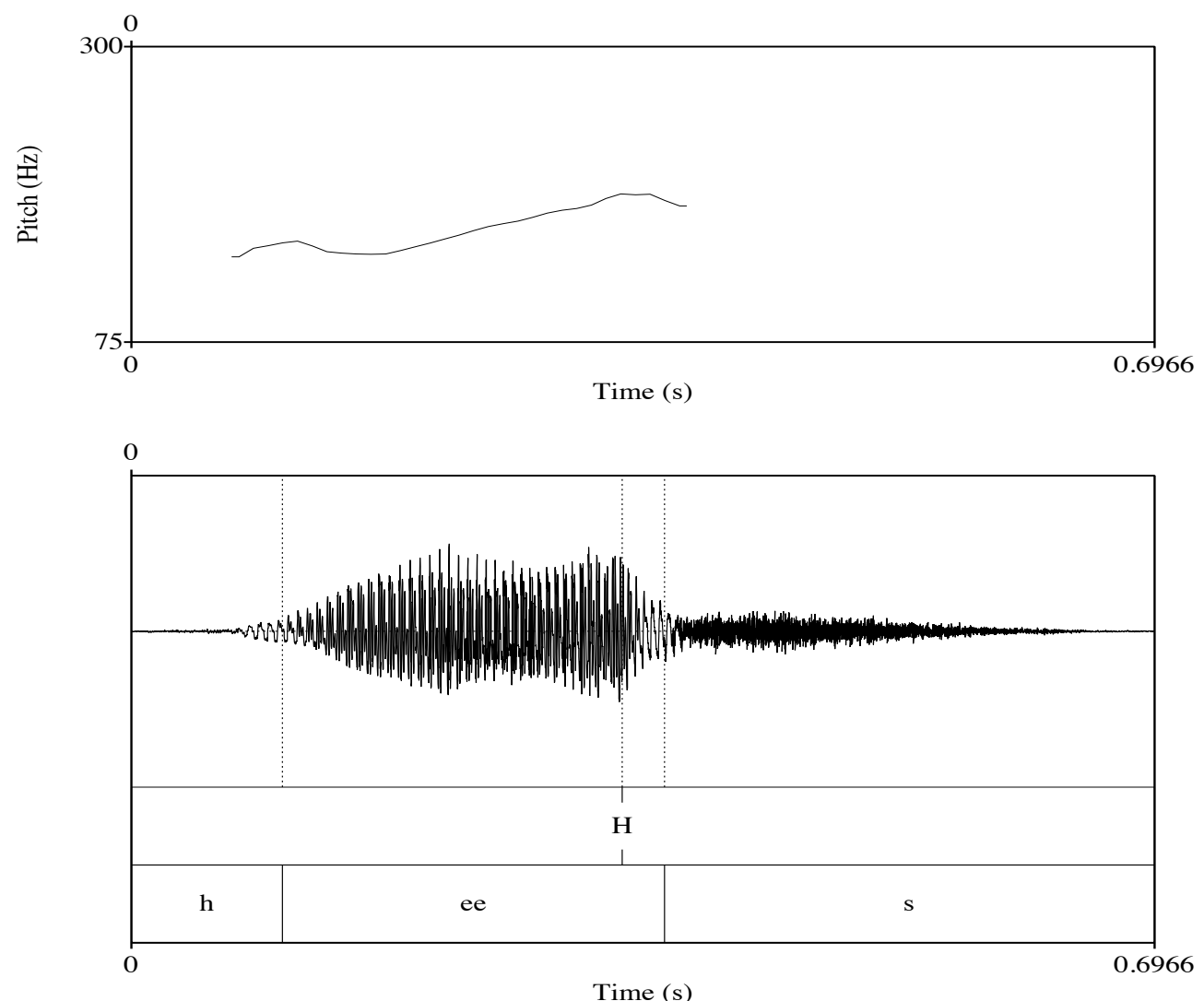
Figure 7 - baré M sg. Abs. 'teacher'
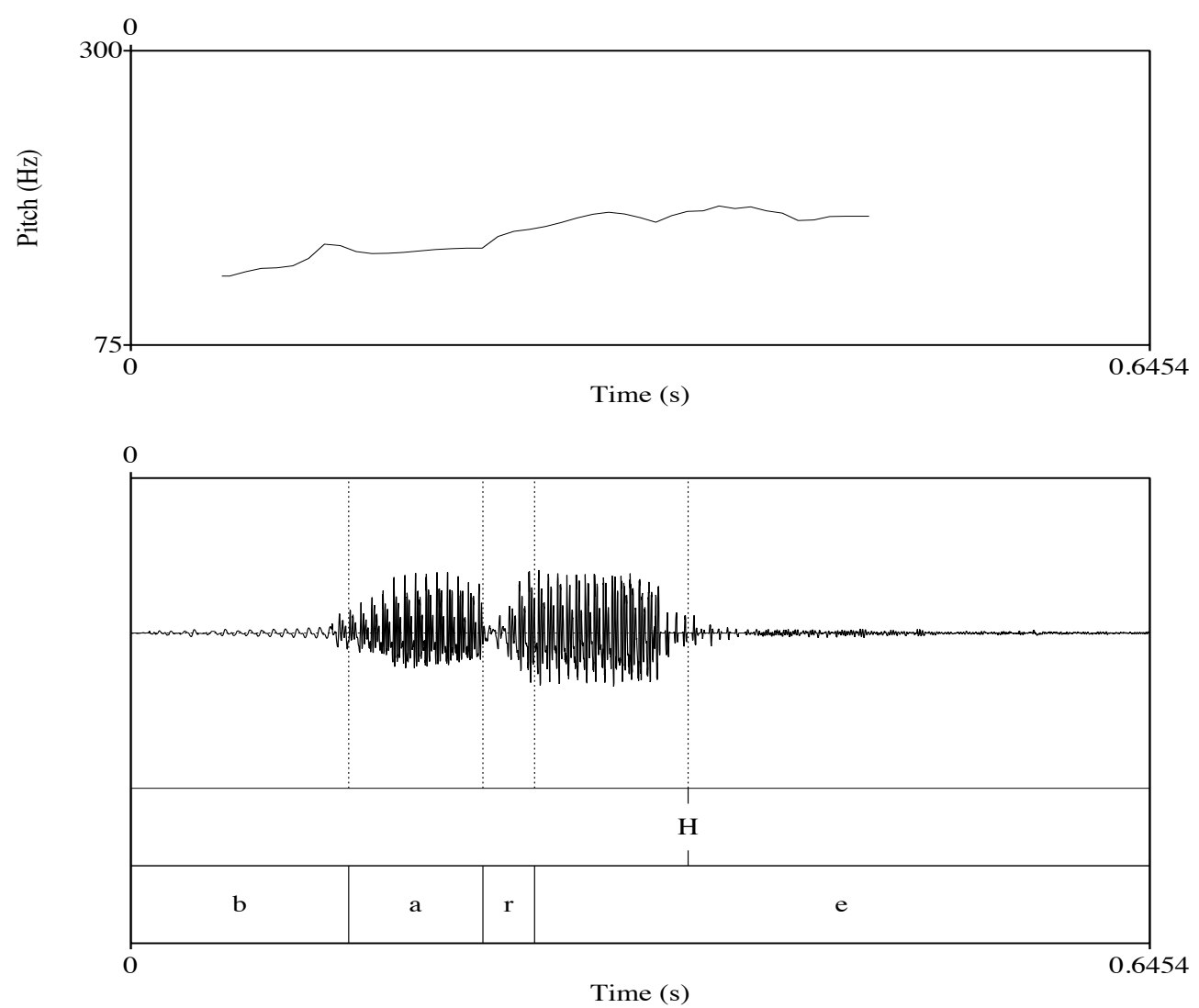

corpus, there is only one case, out of 11 nouns ending in -ó, that displays exceptional behavior. This noun is sheekó F sg. Abs 'tale, story' and it sometimes appears as sheéko at absolutive. I have no explanation this deviance from the general pattern of -ó nouns (cf. Le Gac 2001:65).

The examples provided in this section show that we have two distinct patterns as far as pitch-accent is involved. On the one side, there are those nouns that display a positional contrast of pitch-accent. These nouns distinguish gender through the position of pitch-accent, in line with Hyman's (1981) hypothesis. They belong to what has been labelled type A. On the other, there are two classes, containing only suffixed nouns, which do not distinguish gender through the position of pitch-accent. These are type B nouns.

In the following section, I analyze the opposition between absolutive and 
Figure 8 - shaqó F sg. Abs. 'work'
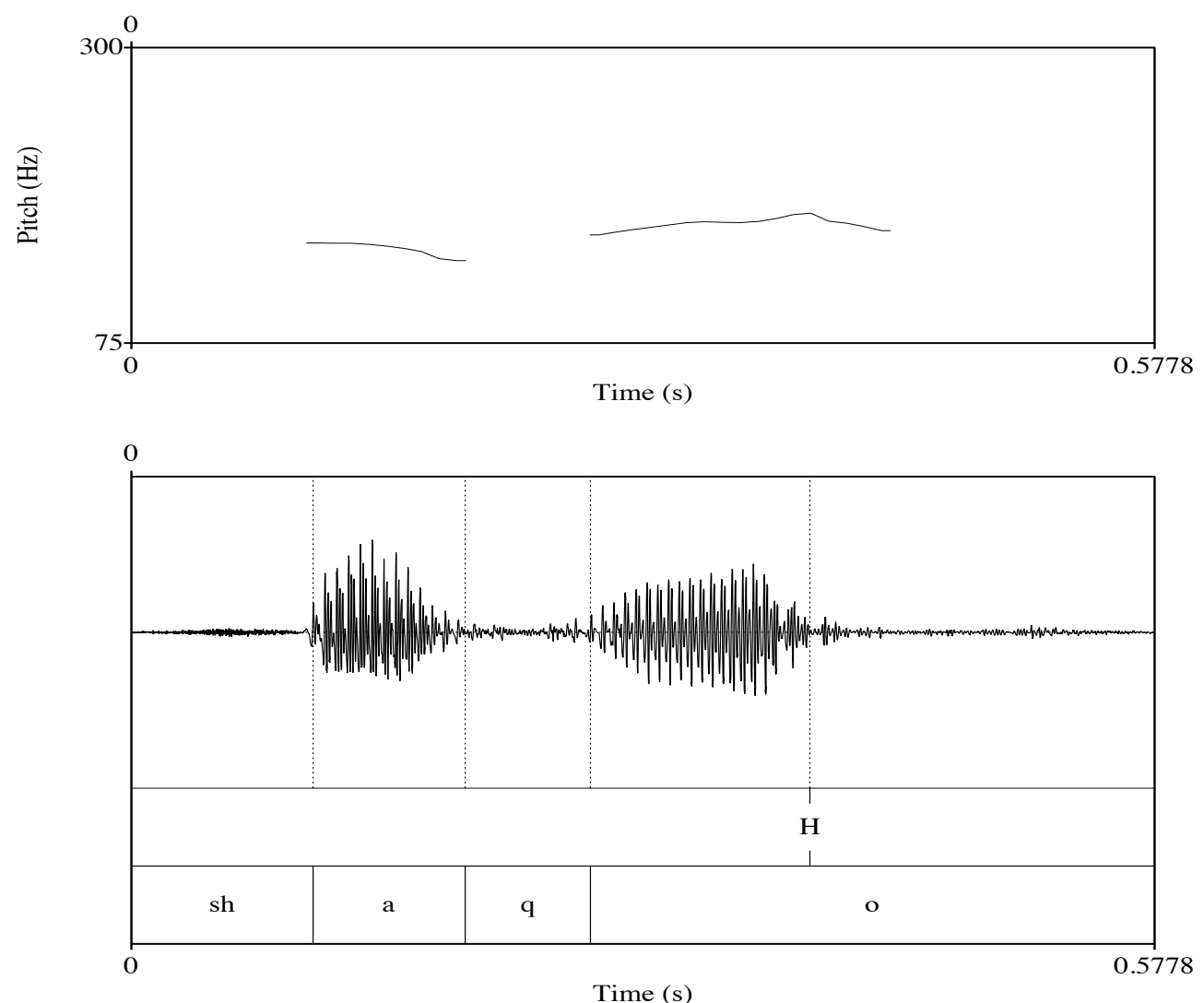
nominative.

\subsection{Abs./Nom. oppositions in Dji}

In addition to plural formation and to the behavior of pitch-accent with respect to the gender, a third aspect of noun inflection in DJI deserves attention: the opposition between absolutive and nominative.

In Som, the nominative case is derived by lowering high tones (Banti 1984; Saeed 1993:141-147) and is used only for unfocussed subjects. Feminine nouns ending in a consonant add the suffix -i. This suffix bears a low tone. As shown in Table 4, the opposition between Abs. and Nom. consists, basically, of the opposition between the presence of pitch-accent vs. its absence. In Table 4, class 3 nouns are not shown because they behave as those in class 4 both in the singular and in the plural. As for the plural forms of type B nouns, I lack reliable data from DJi to propose an analysis. Since Andrzejewski (1964), who affirms that class 6 plurals belong to the sixth declension, whereas class 7 plurals belong to the third declension, these plurals have received little attention in the literature, with the exception of Le Gac (2001).

Table 4 - Nominative patterns

\begin{tabular}{lllllll}
\hline class & type & Abs. & Nom. & gender & number & \\
\hline 1 & $\mathrm{~A}$ & naág & naag-i & $\mathrm{F}$ & $\mathrm{sg}$. & 'woman' \\
1 & $\mathrm{~A}$ & naagó & naago & $\mathrm{M}$ & $\mathrm{pl}$. & 'women' \\
2 & $\mathrm{~A}$ & baabúur & baabuur & $\mathrm{M}$ & $\mathrm{sg}$. & 'truck' \\
2 & $\mathrm{~A}$ & baaburró & baaburro & $\mathrm{F}$ & $\mathrm{pl}$. & 'trucks' \\
4 & $\mathrm{~A}$ & míis & miis & $\mathrm{M}$ & $\mathrm{sg}$. & 'table' \\
4 & $\mathrm{~A}$ & miisás & miisas & $\mathrm{M}$ & $\mathrm{pl}$. & 'tables' \\
5 & $\mathrm{~A}$ & mádax & madax & $\mathrm{M}$ & $\mathrm{sg}$. & 'head' \\
5 & $\mathrm{~A}$ & madáx & madax-i & $\mathrm{F}$ & $\mathrm{pl}$. & 'heads' \\
& & & & & & \\
6 & $\mathrm{~B}$ & baré & bare (báre) & $\mathrm{M}$ & $\mathrm{sg}$. & 'teacher' \\
7 & $\mathrm{~B}$ & shaqó & shaqo (sháqo) & $\mathrm{F}$ & $\mathrm{sg}$. & 'work' \\
\hline
\end{tabular}


According to Le Gac (2001:109-188), the situation is slightly more complex than that depicted by Saeed (1993) (In his 1999 grammar, Saeed changes his description on nominative and claims that nouns belonging to classes 6 and 7 do not lower high tones.) In particular, Le Gac claims that type A nouns behave as expected only in the singular: nominative forms lack high tone. In the plural, in turn, type A nouns lack high tone when they appear both as unfocussed subjects (that is as Nom.) and as unfocussed non-subject NPs. In the latter case, nouns usually take Abs.: we therefore expect plural forms to display high tone. In other words, plurals can display low tone even in a position in which Abs. is selected. Type B Nom. nouns, on the other hand, always display penultimate pitch-accent.

In this paper, I analyze only the singular forms of four distinct nouns. These nouns show that, in type A, Nom. indeed lowers the high tone. In type $\mathrm{B}$, in turn, pitch-accent moves from the last to the penultimate vocalic position. In addition to these facts, the data collected in Djibouti show that the suffix - $\mathbf{i}$ is not spontaneously used by the informants. (I analyze the suffix -i in detail in Lampitelli 2013; recent fieldwork recordings seem to confirm the weakened status of this suffix in DJI. See Lampitelli \& Gac 2016.) In several cases, then, the segmental shapes of Abs. and Nom. forms are identical. ${ }^{19}$

The following nouns are used to illustrate the opposition between absolutive and nominative.

(15) Nouns illustrating the opposition absolutive vs. nominative:
a. ínan cl $2 \mathrm{M} \mathrm{sg}$. Abs. 'boy'
b. inán $\mathrm{cl} 1 \mathrm{~F}$ sg. Abs. 'girl'

\footnotetext{
${ }^{19}$ Some informants are aware of this situation: they think that the deletion of Nom. suffix is a sign of colloquial Somali. This phenomenon is interesting and deserves much more attention in future research on DJI.
} 

c. shímbir ${ }^{20}$ cl $2 \mathrm{M}$ sg. Abs. 'bird'
d. naág cl 1 F sg. Abs. 'woman'
e. tuké cl $6 \mathrm{M}$ sg. Abs. 'crow'

The recordings are selected from two speakers: both are 31 year-old males born in Arta, $40 \mathrm{~km}$ West of Djibouti-ville.

The type A nominative forms inan M sg. 'boy' and inan(-i) F sg. 'girl' are shown in figures 9 and 10, respectively. The contexts in which these nominative forms have been formed are the following: ${ }^{21}$ boy.Nom SM-3SM pass.past.3S here 'A boy passed here.'
a. inan w-úu maray hálkan
b. inan-i w-áy martay hálkan girl-Nom SM-3SF pass.past.3SF here 'A girl passed here.'

Note that inan has absolutely no pitch-accent, whereas in the feminine, inan(-i) displays a weak pitch on the second vowel /a/. This contrast is shown in Figures 9 and 10, respectively. (Additionally, compare Figures 9 and 10 with the corresponding Abs. forms shown in Figures 1 and 2, respectively.) The presence of a weak pitch in Figure 10 is interesting because it is accompanied by the absence of the suffix -i. Djibouti speakers may recognize (16-b) as grammatical, but they won't necessarily produce it spontaneously.

Figure 11 confirms that masculine nominative forms have no high tone. This nominative form has been tested in the following syntactic context:

\footnotetext{
${ }^{20}$ For some speakers of Somali, this noun is F: shimbir-ta bird-the.F.Abs. 'the bird'.

${ }^{21}$ One informant preferred the adverb xágan instead of hálkan. This has no impact on the absence of high tone on subject NP.
} 


\section{shimbir waa duúlayaa}

bird.Nom SM fly.PresProg.3SM

'A bird is flying.'

Finally, Figure 12 illustrates a complex NP: nín iyo naag(-i). The sentence in which the Nom. has been tested is the following:

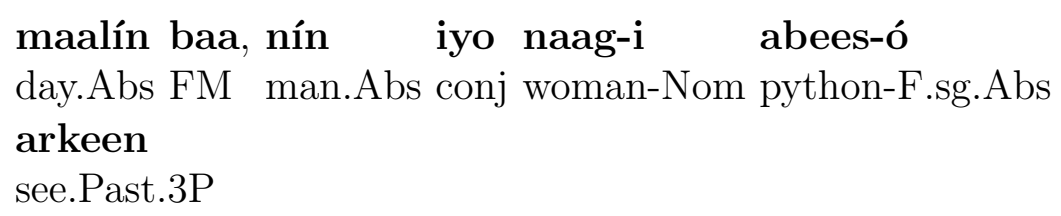

As briefly mentioned in footnote 10 above, in Somali, only the last item within the NP receives the case marking, whereas all the other items take Abs. case. Thus, the clear pitch-accent on nín contrasts with low pitch on naag(-i).

The two feminine examples are interesting. On the one side, inan(-i) (Figure 10) displays high pitch accompanied by the absence of Nom. suffix -i; on the other, naagi (Figure 12) has no pitch but Nom. suffix -i is regularly realized.

Type B nouns, in turn, behave as described by Le Gac (2001): Nom. forms display penultimate pitch-accent, which contrasts with final pitch-accent in Abs. forms. The context in which the opposition has been tested is the following:
a. tuk-é b-aan arkay
crow-M.sg.Abs FM-1S see.Past.1S
'I saw a crow.'
b. túk-e waa duúlayaa crow-M.sg.Nom SM fly.PresProg.3SM
'A crow is flying.'

Figures 13 and 14 show the comparison between tuké M sg. Abs. 'crow' and 
Figure 9 - inan M sg. Nom. 'boy'
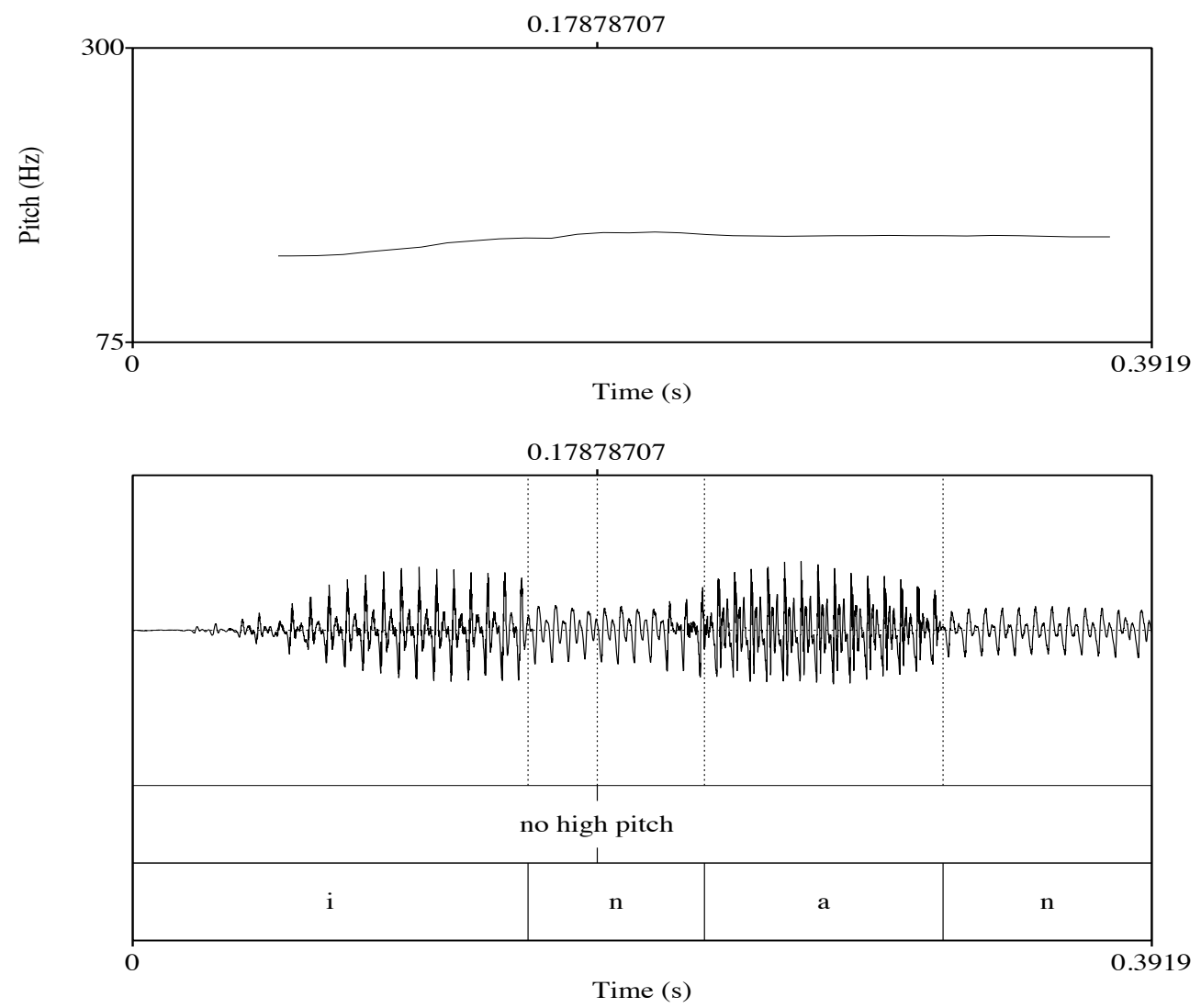

túke M sg. Nom. 'crow', respectively. Note that pitch-accent shifts clearly from the final to the penultimate vowel.

The data confirm the existence of two types of nouns. Type A nouns, which display a clear opposition between high vs. low pitch through Abs. and Nom. forms and type B nouns, which are characterized by pitch-accent shift, whereby Nom. forms display penultimate high tone in contrast with Abs. forms, which have final pitch-accent.

The next section focuses on the status of noun classes in DJI. 
Figure 10 - inan(-i) F sg. Nom. 'girl'
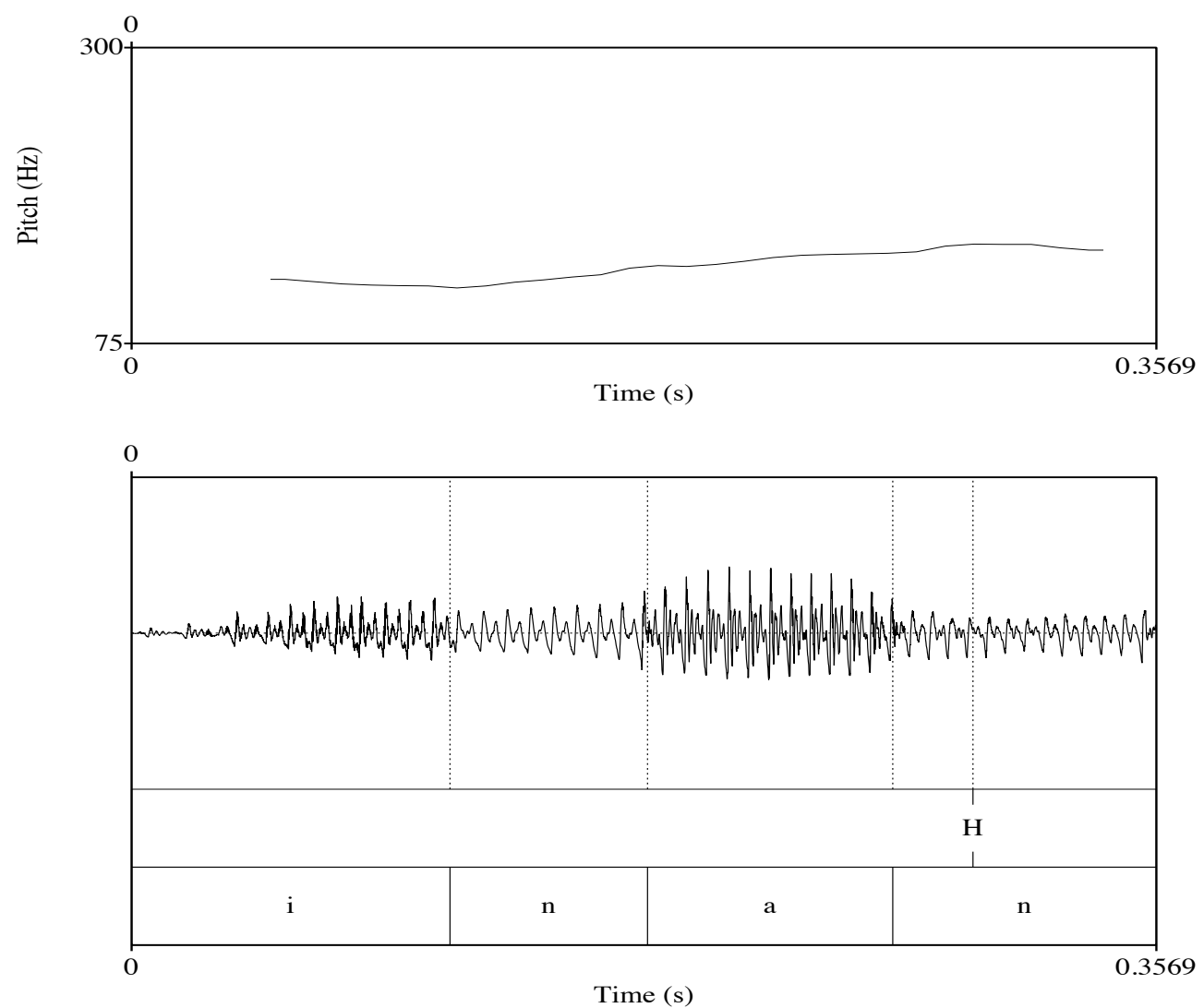
Figure 11 - shimbir M sg. Nom. 'bird'
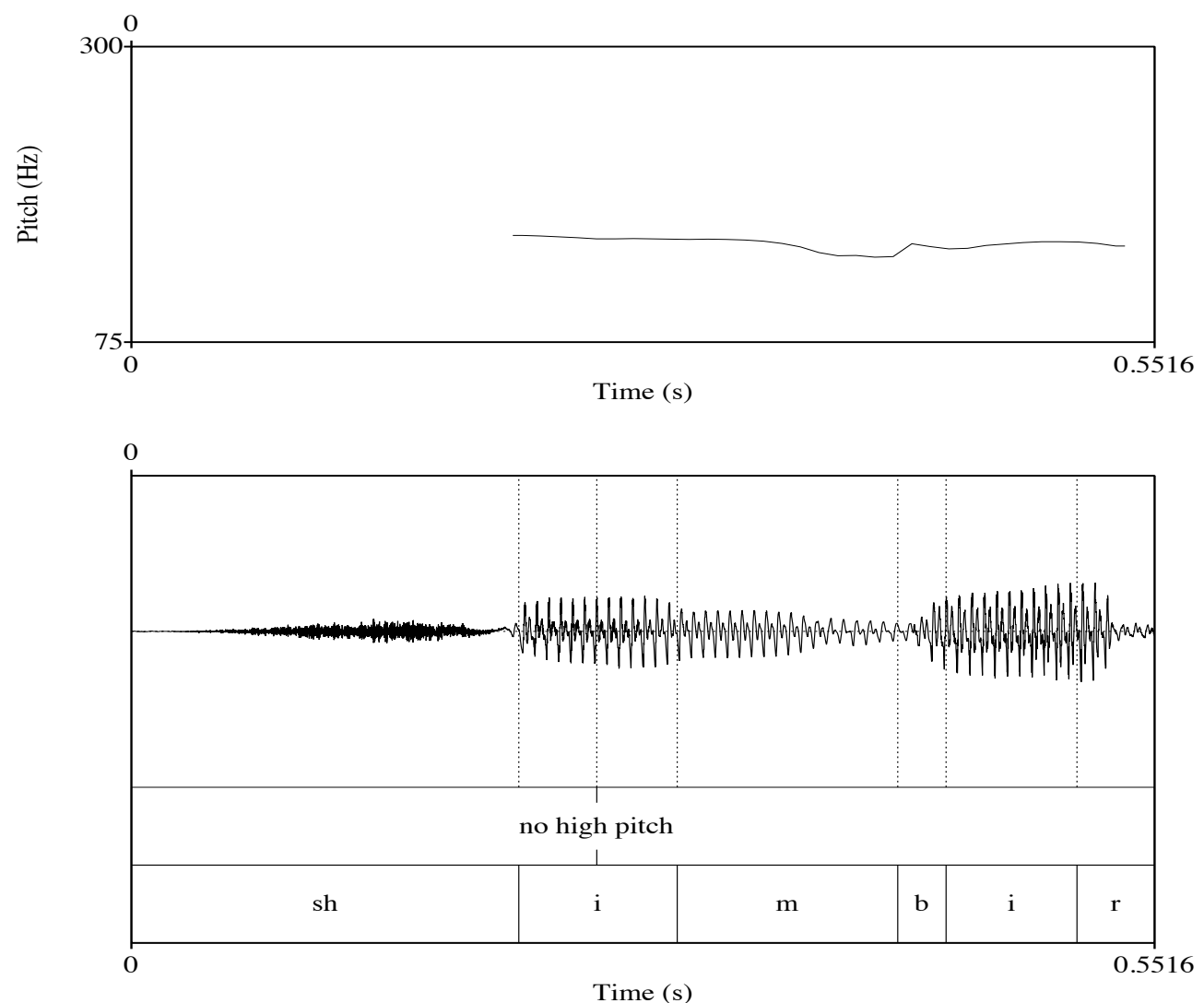
Figure 12 - nín iyo naag(-i) M and F, Nom. '(a) man and (a) woman'
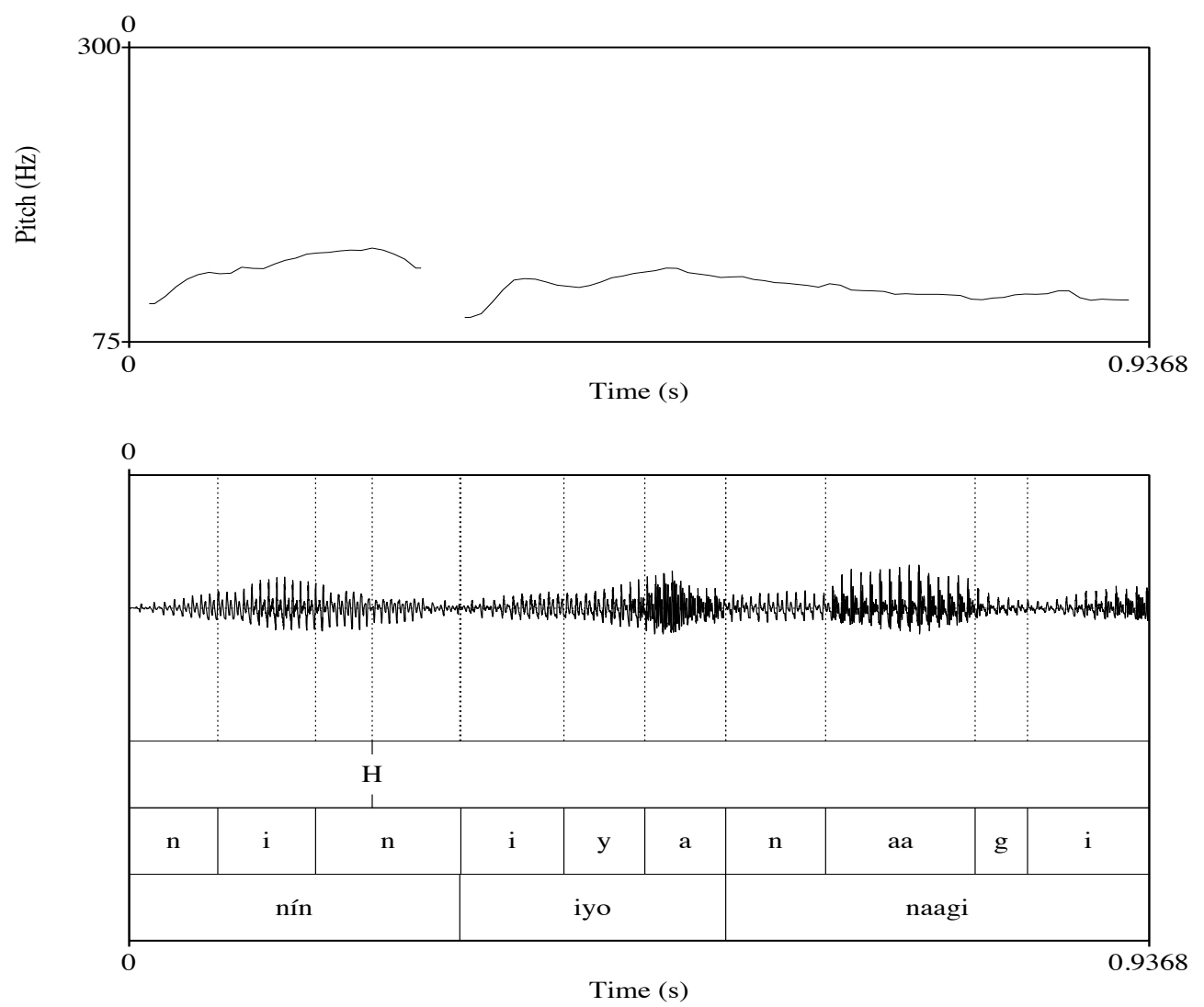
Figure 13 - tuké M sg. Abs.
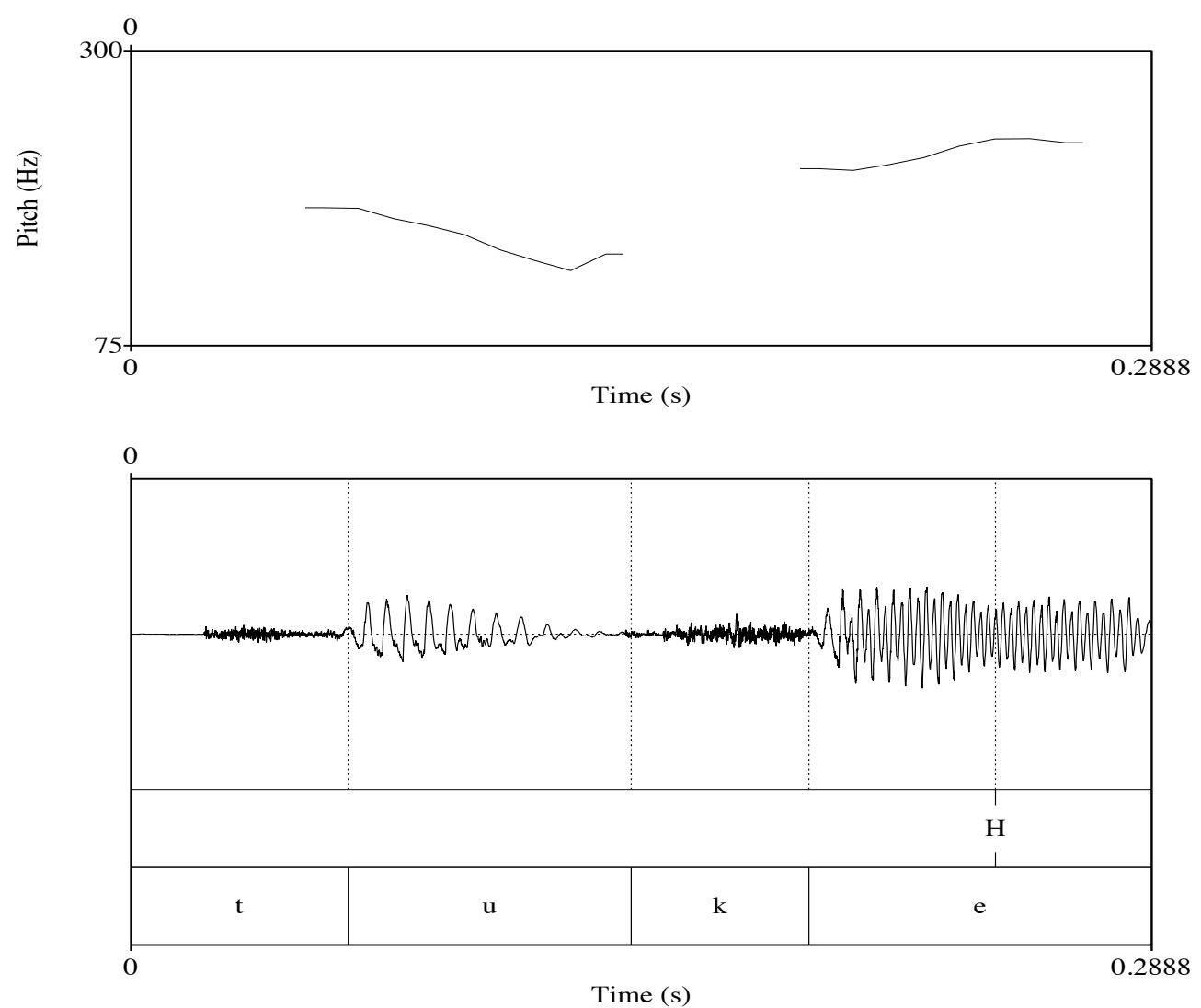

\section{The status of noun classes}

In this section, I discuss the organization of the noun patterns and make the hypothesis that there are only two types of nouns in DJI. The section is divided in two parts: in the first part, I discuss the results of the previous three sections; in the second I sketch out the general lines of a formal analysis accounting for the existence of two morphological types.

\subsection{Type A vs. type B}

DJI adopts mainly suffixation to create a plural. This fact challenges the hypothesis, made on Som data, that seven distinct noun classes exist.

The DJI data, indeed, point to a slightly modified version of this hypothesis. 
Figure 14 - túke M sg. Nom.
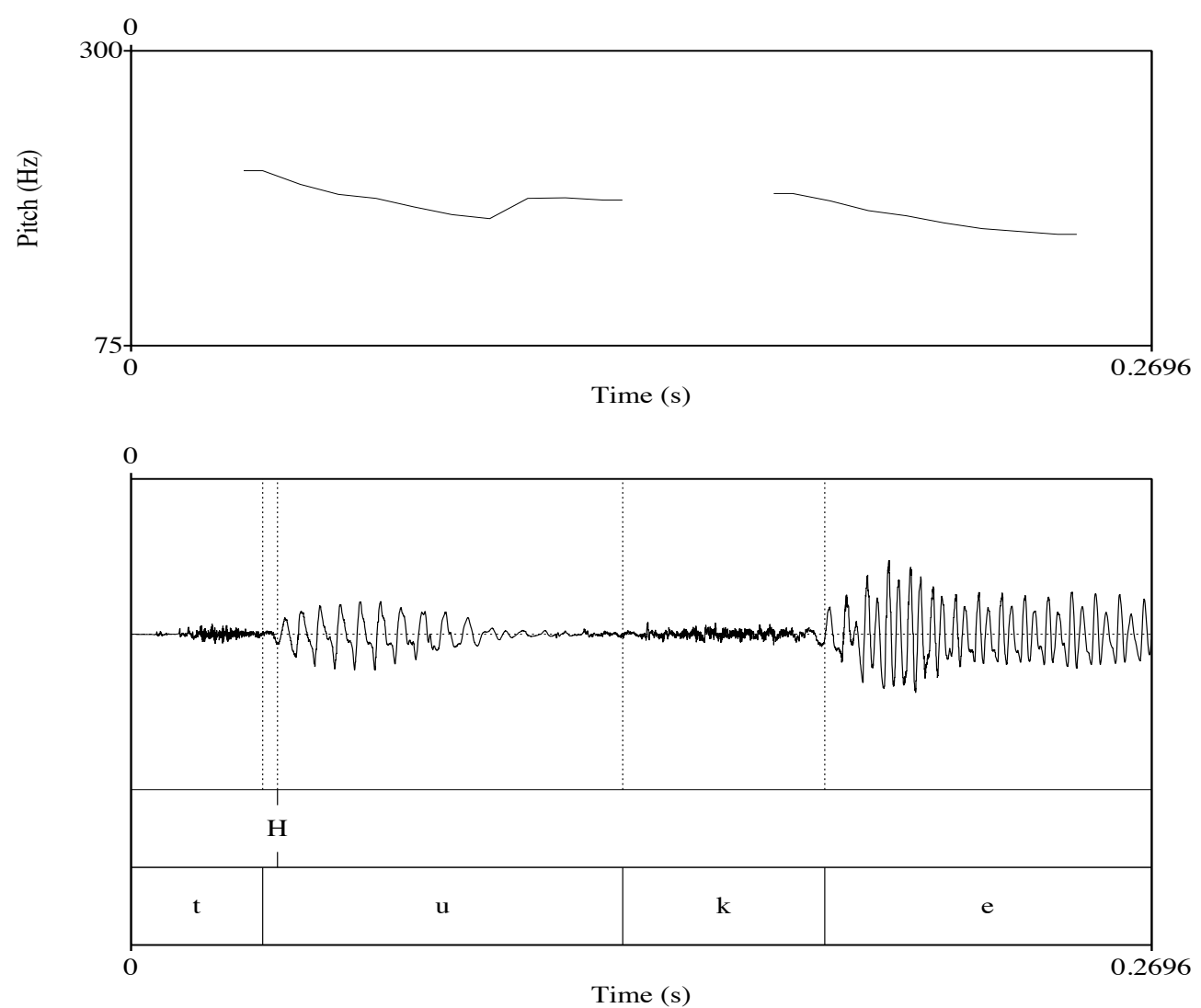

According to Table 2, there are only two relevant plural paradigms. On the one side, we find the suffix -ó, which attaches only to type A nouns (those which are not suffixed in the singular and end in a consonant); on the other, there is suffix -yáal, which attaches to nouns belonging to both types (A and B). In other words, the inflectional behavior depends on the affiliation to either type A or type B.

Now, recall that type A includes non-derived basic nouns. These nouns consist of bare roots ending in a consonant. According to Godon (1998) and later Lampitelli (2013), the constraints which have led Andrzejewski, Banti, Orwin, Puglielli \& Siyaad, and Saeed to postulate up to five classes are predictable and do not justify this inflectional distinction. They claim, rather, that given a root, one can build the right surface form on the basis of regular 
morphophonological principles. In this paper, I build on this hypothesis and assume the following underlying sequence:

$$
\begin{aligned}
& \text { Type A nouns } \\
& \text { root }+ \text { gender }+ \text { number }
\end{aligned}
$$

Type B nouns, in turn, have been analyzed by Lecarme (2002). In her paper, Lecarme claims that these nouns are suffixed in the singular and therefore proposes that the suffixes -e and -o should be analyzed as nominalizers, that is suffixes turning the item to which they attach to into a noun. Note that gender can be predicted from the nature of the suffixed vowel: -e is $\mathrm{M}$, whereas -o is F. ${ }^{22}$ Therefore, these nominalizers occupy the same place as gender in type A nouns. This observation allows us to analyze type B nouns as follows:

$$
\begin{aligned}
& \text { Type B nouns } \\
& \text { root }+ \text { nominalizer }+ \text { number }
\end{aligned}
$$

The dichotomy between type A and type B can be schematized as follows:

\footnotetext{
${ }^{22}$ One may ask whether the suffix -o found in class 7 is the same suffix appearing in plural forms in type A. I don't have an answer to this question, and leave it open for future work. Note, however, that these suffixes don't have the same distribution with respect to both gender and number: class 7 -o is found only in feminine singular nouns, whereas type A -o is found only in plural forms that can be either masculine or feminine.
} 
Inflectional types in DJI

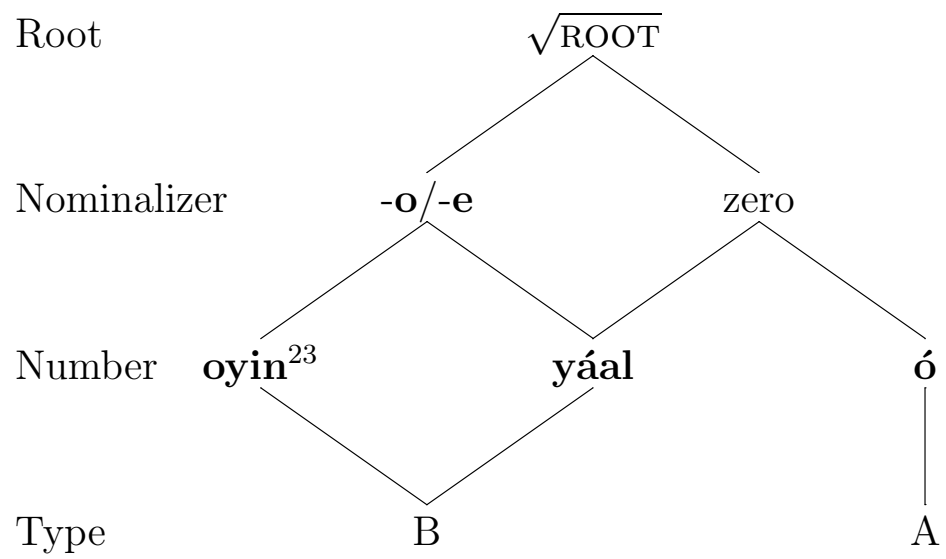

The situation depicted in the diagram above allows us to claim that, in DJI, noun classes are epiphenomenal. Given a root, one has to know only whether it selects for a suffix or not. Plural is then built accordingly. Pitch-accent is associated to each noun independently from the affiliation to either groups (cf. Lampitelli 2013, where I claim that pitch-accent is the exponent of syntactic case: I return to this point in the next section.)

The existence of only two morphological types is supported by the behavior of pitch-accent. As shown in Section 3.3, type A nouns display positional contrast of pitch-accent. This contrast is used to distinguish the gender of the noun. Type B nouns, in turn, have final pitch-accent: the high tone is associated to the nominalizer (-e and -o). This situation strengthens the hypothesis in (22).

The opposition between two types of nouns is also found in the expression of nominative. As we saw, in type A, nominative is characterized by the absence of pitch-accent, whereas in type $\mathrm{B}$, nominative does display pitch-accent but in a different position with respect to absolutive.

We can conclude that the basic non-derived nouns belong to type A,

\footnotetext{
${ }^{23}$ The suffix -oyin occurs in two items belonging to class 4 (type A). I don't have an explanation of this deviant pattern, which remains exceptional (see Table 2 above.)
} 
whereas suffixed nouns belong to type B. This dichotomy can be regarded as the opposition between null nominalizer and overt nominalizer. I formalize this hypothesis in the next subsection.

\subsection{The basic pieces of Dji nouns}

According to the theory of Distributed Morphology (Halle \& Marantz 1993; Embick 2010), nouns are created by a syntactic operation called merge. This operation creates a syntactic tree in which a category defining head called 'little n' takes a root as its complement. Since Ritter (1991) and later Lowenstamm (2008), gender is assigned to nouns in $n$. Lexical affiliation is expressed, in Distributed Morphology, as the merge of syntactic categories. The syntactic structure $\mathrm{nP}$ is selected by the head num: this head introduces those morphemes that express number on nouns. In other words, num hosts the plural suffix.

As for Somali, the question is whether its plural is inflectional or derivational. The distinction inflection/derivation does not have clear theoretical status in Distributed Morphology. However, according to Marantz (2007) and Embick (2010), derivational morphemes correspond to category-defining heads like $n$, whereas inflection corresponds to those heads that do not define any functional category. In the case at hand, this head is num.

In the remainder of this section, I propose a Distributed Morphology analysis of both type A and type B nouns. More precisely, I claim that type A plurals are inflectional (thus introduced by the head num), whereas type B nouns are derivational.

In type A, only basic and non-derived nouns appear. This means that the category defining head $n$ is phonologically empty, because no specific suffix appears. In type $\mathrm{B}$, in turn, the nominalizer has two allomorphs: -e and -o. 
These vowels share an interesting phonological property: they both alternate with -a- when they are not final. This occurs when the determiner is suffixed:

(23) class 6
a. bar-é
teach-M.sg.Abs
teacher
b. bar-á-ha
teach-M.sg.Abs-Det.M.Abs
the teacher

(24) $\quad$ class 7
a. shaq-ó
work-F.sg.Abs
work
b. shaq-á-da work-F.sg.Abs-Det.F.Abs the work

In addition to these examples, there are two cases of morphological [o]'s which alternate with $[\mathbf{a}]$. As shown above, cf. Section 2, plural suffix -ó alternates with -á- in exactly the same situation as that shown in (24): when the determiner is suffixed to a plural, final [o] becomes [a] (cf. Godon 1998 and Lampitelli 2013 for details and analysis). The second case is the autobenefactive suffix -o, which appears in imperative singular of conjugation 3 (3A: qaadó 'to take for oneself', 3B: joogsó 'to stop'). Finite verbal forms are created by adding suffixes to the stem of the imperative singular. Crucially, -o is always replaced by -a-: 1sg. joogsa-day 'I stopped', 2sg. joogsa-tay 'you stopped', etc. (cf. Saeed 1993:51-58 for details involving the conjugation and Barillot \& Ségéral 2005 for an analysis of this alternation.)

These alternations raise the question of whether these vowels share some 
underlying phonological object. I leave this analytical path open for future research.

I propose the following two phonological exponents of $n$ :

(25) Exponents of $n$ :
a. $\quad n \Longleftrightarrow$ zero $\sqrt{\text { ROOT }}($ type $\mathrm{A})$
b. $n \Longleftrightarrow-\mathbf{e} /-\mathbf{o} \sqrt{\mathrm{ROOT}}($ type $\mathrm{B})$

The exponent (25-a) is selected for by a root belonging to type A, whereas the exponent $(25-\mathrm{b})$ is selected for by a root belonging to type B. In type $\mathrm{B}$, the gender associated to the root triggers the agreement with the head $n$ (see Acquaviva 2009): -e is selected by M gender, whereas -o is selected by F gender.

I illustrate the structure of both a feminine and a masculine noun belonging to type $\mathrm{A}$ in (26) and (27), respectively. The structure of a type B noun is shown in (28).

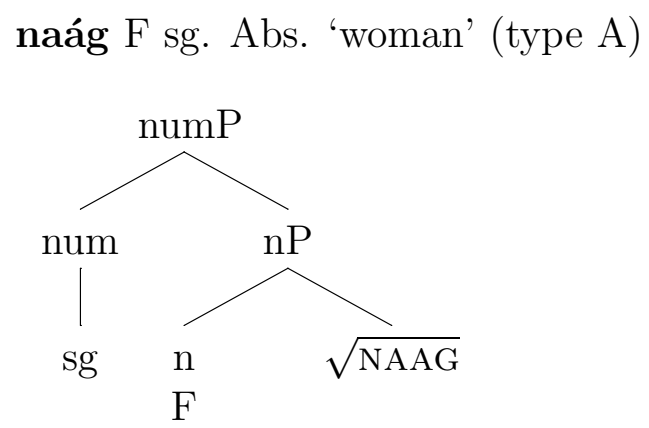

(27) baabúur M sg. Abs. 'truck' (type A)

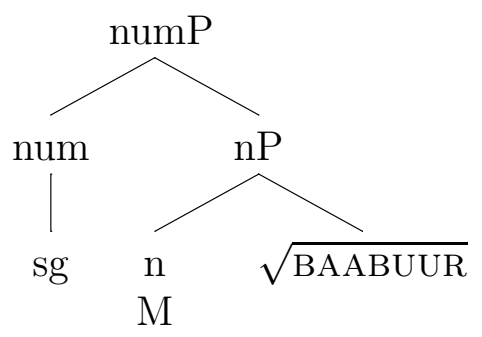


baré M sg. Abs. 'teacher' (type B)

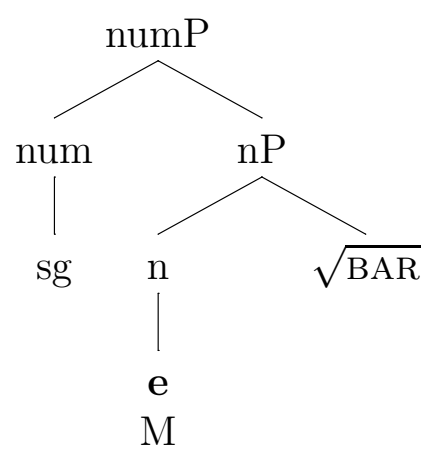

As for plural, we have two suffixes, -ó and -yáal (I leave the suffix -oyin aside and will not analyze it). The structures of both a masculine and a feminine plural ending in -ó are shown below:

naagó $\mathrm{M}$ pl. Abs. 'women' (type A)

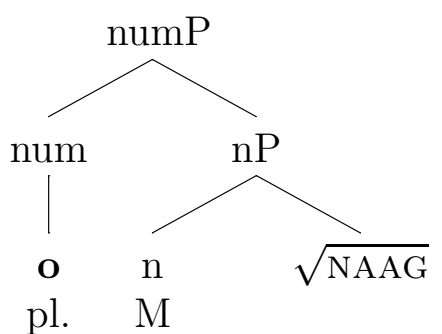

(30) baabuurró F pl. Abs. 'trucks' (type B)

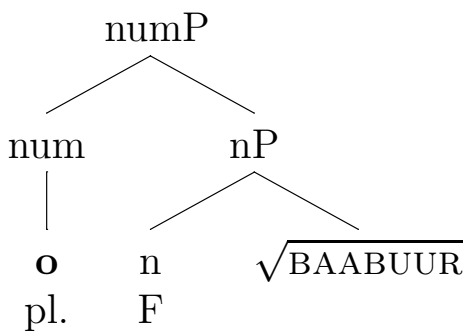

Recall, from Table 1, that all $\mathrm{F}$ plural forms belonging to class 2 display gemination of the last consonant of the stem (unless the consonant cannot geminate, in such a case $\mathbf{y}$ is inserted: daríiq 'road' vs. dariiq-y-ó 'roads'.) The gemination of the last consonant of the stem has been accounted for by positing that $\mathrm{F}$ gender is marked by an external syllable. This provides the 
phonological space for the gemination to occur only in the plural (the singular baabúur is M). Cf. Godon (1998) and Lampitelli (2013) for detailed analyses in an autosegmental framework.

The suffix -yáal, in turn, deserves more attention. It attaches to any type of nouns: both $\mathrm{A}$ and $\mathrm{B}$ and, in addition, it imposes its own gender, feminine (contrarily to what -ó does). For this reason, following Lahrouchi \& Lampitelli (2014), I propose that the suffix -yáal is a root, in the sense of Lowenstamm (2014), i.e. it is a bound root, whose distribution is determined by its selectional restriction. $\sqrt{\mathrm{YAAL}}$ selects for $\mathrm{nPs}$.

(31) barayáal F pl. Abs. 'teachers' (type B)

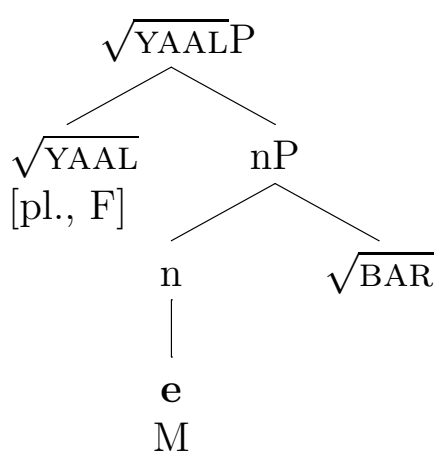

(32) madaxyáal F pl. Abs. 'heads' (type A)

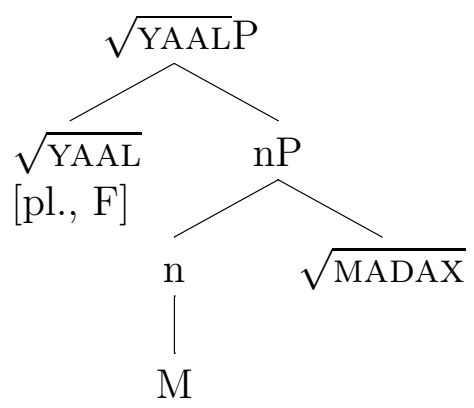

The formal distinction between -ó and -yáal is accounted for by their different morphological structure: the former is a simple exponent, whereas the latter is a root and, as such, has selectional power. ${ }^{24}$ In other words, -o is an

\footnotetext{
${ }^{24}$ One may think of suffix -oyin as an affixal root, too. Note, however, that -oyin has
} 
inflectional morpheme, whereas -yáal behaves like a derivational affix. The hypothesis that -yáal is an affixal root makes an interesting prediction regarding its syntactic behavior: it could attach, in principle, to any functional projection. This is actually the case: -yáal appears in plural of plural constructions, such as naagayáal /naag+o+yaal/ 'groups of women', see Appendix A for a few examples of such plurals. ${ }^{25}$

The last basic ingredient of DJI nouns is pitch-accent. In Lampitelli (2013), I claim that pitch-accent is the exponent of syntactic case. DJI data confirms this hypothesis as far as Abs. and Nom. are concerned: the position of pitchaccent is indicative of the syntactic case in both type $\mathrm{A}$ and type $\mathrm{B}$. The complete treatment of syntactic case being beyond the scope of this paper, I will not go further into it. ${ }^{26}$

To sum up, one needs to know whether a given root belongs to either type A or type B. The exponent of $\mathbf{n}$ is then selected for accordingly: type A selects for zero, whereas type B selects for suffixes -e/-o depending on gender. Finally, plural suffix -o attaches only to type $A$ and the affixal root $\sqrt{\text { YAAL }}$ attaches to

distributional restrictions with respect to -yáal. The former attaches basically to class 7. (F nouns, cf. Table 2), whereas the latter attaches to any type of noun with a strong preference for those nouns which are $\mathrm{M}$ in the singular. The question of whether this distributional difference depends exclusively on the gender of the singular or not leads to an interesting debate. I leave it open for further developments.

${ }^{25}$ Lecarme (2002) and Kramer (2015:147-150) propose a derivational analysis of suffix -o within a Distributed Morphology framework. As mentioned above, Maniscalco (2015) proposes an analysis treating Somali noun classes as typical noun classes, like those in Bantu languages. Within this view, plural can be easily analyzed as being always derivational, as suggested by one of the anonymous reviewers. See Schadeberg (2003) on this point.

${ }^{26}$ The discussion involves primarily the underlying structure of a noun: does Somali display the functional projection K(ase) or not? Lecarme (2002:129) proposes that Somali lacks KP, whereas Lampitelli (2013) follows Calabrese (1998) in postulating such a projection in Somali. Secondarily, the discussion deals with the phonological exponent of syntactic case. In the approach proposed in this paper, it follows that pitch-accent marks syntactic case. In other approaches, such as Lecarme's (2002), pitch-accent is lexically associated to plural exponent -ó. Thirdly, we saw that pitch-accent follows two distinct patterns with respect to the type: in type A, pitch-accent has two distinct positions for masculine and feminine, respectively, but it disappears in the nominative case; in type $\mathrm{B}$, in turn, gender is never distinguished by the position of pitch-accent and Nom. does not lower high tones. What triggers two different behaviors of pitch-accent? Further research will have to discuss these issues by building on additional data from DJI. 
both types. Note that the hypothesis defended here explains why -yáal selects for both types, but it doesn't explain why the segmental suffix -o displays restrictive selectional distrubution: it does not attach to type B. In other words, one might expect the following plural to be attested: $* / \mathbf{b a r}+\mathbf{e}+\mathbf{o} /=$ *barao 'teachers'. These plurals don't exist and are totally ungrammatical. I leave this issue for further work.

Table 5 recapitulates the situation.

Table 5 - The basic pieces of DJI nouns

\begin{tabular}{|c|c|c|c|c|}
\hline type & roots & $\mathrm{n}$ & num & examples \\
\hline A & $\sqrt{ }($ list 1) & zero & -O $\sqrt{\text { YAAL }}$ & naág 'woman', mádax 'head', etc. \\
\hline B & $\sqrt{ }($ list 2) & $-\mathbf{e} /-\mathbf{o}$ & $\sqrt{\text { YAAL }}$ & baré 'teacher', shaqó 'work' \\
\hline
\end{tabular}

\section{Conclusion}

This paper showed the interesting patterns of pluralization in DJI. Stemming from the observation that pluralization involves mainly two suffixes, I put forward the hypothesis that the noun system of DJI consists of two types:

\section{DJI noun types}

a. Type A (basic and non-derived nouns)

b. Type B (suffixed nouns)

As a consequence, the complex system of noun classes, proposed by various authors (Andrzejewski 1964, 1979; Banti 1988; Orwin 1995; Saeed 1993, 1999), looks simplified. Following Godon (1998) and Lampitelli (2013), I proposed that a DJI noun is made up of a root followed by a nominalizer (either null or vocalic: -e/-o). Plural is then built by suffixation. The behavior of pitchaccent offers an additional argument for the existence of two inflectional types. 
Type A nouns display positional contrast between masculine and feminine, whereas type B nouns neutralize this contrast. Finally, the dichotomy between type A and type B is confirmed by the opposition absolutive vs. nominative. In type A, nominative lowers high tones: the contrast between absolutive and nominative is based on the contrast between high and low tones. In type B nouns, in turn, nominative is characterized, as already noticed by Le Gac (2001), by shifting the pitch-accent one vocalic unit leftwards.

The three parameters used to determine the two types are summarized below:
a. Two pluralization patterns: -ó/-yáal (type A) vs. -yáal/-oyin (type B)
b. Two positional contrasts for gender: final/penultimate (type A) vs. final (type B)
c. Two positional contrasts for Abs./Nom.: presence/absence of pitch- accent (type A) vs. final vs. penultimate pitch-accent (type B)

Further developments of this research will have to provide new data to support the hypothesis of two noun types and propose a full formal analysis of noun structures in DJI.

Acknowledgements: This work benefited from travel funds granted by the research Lab Laboratoire de Linguistique Formelle (UMR 7110 Université Paris Diderot and CNRS): I wish to thank those former colleagues who helped me prepare my fieldwork activity in Djibouti in 2012. I am also grateful to my informants and especially to Ragueh, Moubarak, Houssein and Abdirachid for sharing their beautiful language with me. Finally, I thank two anonymous 
Journal of African Languages and Linguistics referees for valuable comments and remarks. All remaining errors are, of course, my own responsibility. 


\section{Abbreviations}

$\begin{array}{ll}\text { Abs } & \text { Absolutive } \\ \text { C } & \text { Onset, consonant } \\ \text { CAPITAL FONT } & \text { Focussed phrase } \\ \text { Det } & \text { Determiner } \\ \text { F } & \text { Feminine } \\ \text { FM } & \text { Focus marker } \\ \text { H } & \text { High pitch } \\ \text { irr } & \text { Irregular plural } \\ \text { M } & \text { Masculine } \\ \text { Nom } & \text { Nominative } \\ \text { PA } & \text { pitch-accent } \\ \text { pl } & \text { Plural } \\ \text { Ppl } & \text { Plural of plural } \\ \text { Prep } & \text { Preposition } \\ \text { Pres } & \text { Present tense } \\ \text { Pro } & \text { Pronoun } \\ \text { Prog } & \text { Progressive } \\ \text { rdp } & \text { Reduplicated plural } \\ \text { Red } & \text { Reduced paradigm } \\ \text { sg } & \text { Singular } \\ \text { SM } & \text { Sentence marker } \\ \text { V } & \text { Nucleus, vowel }\end{array}$




\section{References}

Acquaviva, Paolo. 2009. Roots and lexicality in distributed morphology. In Alexandra Galani, Daniel Redinger \& Norman Yeo (eds.), York-Essex morphology meeting 2, 1-21. York.

Andrzejewski, Bogumił Witalis. 1956. Accentual patterns in verbal forms in the Isaaq dialect of Somali. Bulletin of the School of Oriental and African Studies 1(1). 103-129.

Andrzejewski, Bogumił Witalis. 1964. The declensions of Somali nouns. London: School of Oriental and African Studies.

Andrzejewski, Bogumił Witalis. 1979. The case system in Somali. London: School of Oriental and African Studies.

Andrzejewski, Bogumił Witalis. 1984. The role of accentual patterns in subject/object differentiation in Somali and its parallels in Paranilotic languages. In James Bynon (ed.), Current progress in Afro-Asiatic linguistics: Papers of the third international Hamito-Semitic congress, 11-15. Amsterdam: John Benjamins.

Armstrong, Lilias. 1934. The phonetic structure of Somali. Mitteilungen des Seminars für orientalische Sprachen 37. 116-161.

Banti, Giorgio. 1984. The morphology of the nominative in Somali. In Wolfgang U. Dressler, Oskar E. Pfeiffer \& John R. Rennison (eds.), Discussion papers for the fifth international phonology meeting, 27-31. Wien: Wiener Linguistische Gazette.

Banti, Giorgio. 1988. Two Cushitic systems: Somali and Oromo. In Harry 
van der Hulst \& Norval Smith (eds.), Autosegmental studies on pitch accent, 11-49. Dordrecht: Foris.

Banti, Giorgio. 2011. Somali language. In Siegbert Uhlig (ed.), Encyclopaedia aethiopica, 693a-696b. Wiesbaden: Harrassowitz.

Barillot, Xavier. 2002. Morphophonologie gabaritique et information consonantique latente en somali et dans les langues est-couchitiques: Université Paris VII dissertation.

Barillot, Xavier \& Philippe Ségéral. 2005. On phonological processes in the "3rd conjugation" of Somali. Folia Orientalia 41. 115-131.

Calabrese, Andrea. 1998. Some remarks on the Latin case system. In José Lema \& Esthela Treviño (eds.), Theoretical analyses of Romance languages. Selected papers from the $26^{\text {th }}$ Linguistic Symposium on Romance Languages (LSRL XXVI), Mexico City, 28-30 March 1996, 71-126. Amsterdam/Philadelphia: Benjamins.

Embick, David. 2010. Localism versus globalism in morphology and phonology. Cambridge, MA: MIT Press.

Frascarelli, Mara \& Annarita Puglielli. 2005. The focus system in Cushitic languages. In Paolo Fronzaroli \& Paolo Marrassini (eds.), Proceedings of the 10th Hamito-Semitic congress. Afroasiatic linguistics, 333-358. Florence: Università di Firenze, Dipartimento di Linguistica.

Frascarelli, Mara \& Annarita Puglielli. 2007a. Focus in the force-fin system. Information structure in Cushitic languages. In Aboh Enoch, Katharina Hartmann \& Malte Zimmermann (eds.), Focus strategies: Evidence from African languages, 161-184. Berlin: Mouton de Gruyter. 
Frascarelli, Mara \& Annarita Puglielli. 2007b. Focus markers and universal grammar. In Azeb Amha, Maarten Mous \& Graziano Savà (eds.), Omotic and Cushitic language studies. Papers from the fourth Cushitic and Omotic conference, Leiden 10-12 April, 2003, 169-185. Köln: Rüdiger Köppe.

Gebert, Lucyna. 1986. Focus and word order in Somali. Afrikanistische Arbeitspapiere 5. 43-69.

Godon, Elsa. 1998. Aspects de la morphologie nominale du somali: la formation du pluriel. Mémoire de DEA, Université Paris VII.

Halle, Morris \& Alec Marantz. 1993. Distributed morphology and the pieces of inflection. In Kenneth Hale \& Samuel Jay Keyser (eds.), The view from building 20, 111-176. Cambridge, MA: MIT Press.

Hyman, Larry. 1981. Tonal accent in Somali. Studies in African Linguistics 12(2). 169-203.

Kramer, Ruth. 2015. The morphosyntax of gender. Oxford: Oxford University Press.

Lahrouchi, Mohamed \& Nicola Lampitelli. 2014. On plurals, noun phrase and num(ber) in Moroccan Arabic and Djibouti Somali. In Sabrina Bendjaballah, Noam Faust, Mohamed Lahrouchi \& Nicola Lampitelli (eds.), The form of structure, the structure of form, 303-314. Amsterdam: John Benjamins.

Lampitelli, Nicola. 2013. The decomposition of Somali nouns. Brill's Annual of Afroasiatic Languages and Linguistics 5. 117-158.

Lampitelli, Nicola \& David Le Gac. 2016. Remarks on the nominative case in Somali. Paper presented at the Phonetics and Phonology of Somali Workshop, Leiden University, 1 September. 
Le Gac, David. 2001. Structure prosodique de la focalisation : le cas du somali et du français: Université Paris VII dissertation.

Le Gac, David. 2003. Marques prosodiques de la focalisation contrastive en somali. In Anne Lacheret-Dujour \& Jacques François (eds.), Fonction et moyens d'expression de la focalisation à travers les langues, 49-80. Leuven: Peeters.

Lecarme, Jacqueline. 2002. Gender 'polarity': Theoretical aspects of Somali nominal morphology. In Paul Boucher (ed.), Many morphologies, 109-141. Somerville, MA: Cascadilla Press.

Lowenstamm, Jean. 2008. On little $n, \sqrt{ }$ and types of nouns. In Jutta Hartmann, Veronika Hegedus \& Henk van Riemsdjik (eds.), The sounds of silence: Empty elements in syntax and phonology, 105-143. Amsterdam: Elsevier.

Lowenstamm, Jean. 2014. Derivational affixes as roots: Phasal spell-out meets English stress shift. In Artemis Alexiadou, Hagit Borer \& Florian Schäfer (eds.), The syntax of roots and the roots of syntax, 230-258. Oxford: Oxford University Press.

Maniscalco, Samuele. 2015. The gender system of Somali. Humboldt Universitat zu Berlin: MA Thesis.

Marantz, Alec. 2007. Phases and words. In Sook-Hee Choe (ed.), Phases in the theory of grammar University of Seoul, 199-222. Seoul: Dong In.

Meinhof, Carl. 1912. Die Sprachen der Hamiten. Hamburg: L\&R Friederischen. 
Mioni, Alberto. 1988. Italian and English loanwords in Somali. In Annarita Puglielli (ed.), Proceedings of the Third International Congress of Somali studies, 36-42. Roma: Il Pensiero Scientifico Editore.

Morin, Didier. 1986. Contes de Djibouti. Paris: Conseil international de la langue française: Edicef.

Morin, Didier. 2003. Littérature djiboutienne : une littérature entre hiatus et lapsus. In Littérature $\&$ espaces. Actes du XXXe Congrès de la Société française de littérature comparée, 2001, Limoges, 20-22 septembre 2001, 341-351. Paris-Louvain: Peeters.

Orwin, Martin. 1995. Colloquial Somali: A complete language course. New York: Routledge.

Paster, Mary. 2010. Optional multiple plural marking in Maay. In Franz Rainer, Wolfgang U. Dressler, Dieter Kastovsky \& Has Christian Luschutzky (eds.), Current issues in linguistic theory 310: Variation and change in morphology, 177-192. Amsterdam: John Benjamins.

Puglielli, Annarita \& Cabdallah Mansuur (eds.). 2012. Qamuuska afsoomaaliga. Rome: UniTrePress.

Puglielli, Annarita \& Mohamed Siyaad. 1984. La flessione del nome. In Annarita Puglielli (ed.), Studi somali 5: Aspetti morfologici lessicali e della focalizzazione, 53-112. Roma: Min. Affari Esteri, Dir. Generale per la Cooperazione allo Sviluppo.

Ritter, Elizabeth. 1991. Two functional categories in noun phrases: Evidence from Modern Hebrew. In Susan Rothstein (ed.), Syntax and semantics, 37-62. San Diego: Academic Press. 
Saeed, John Ibrahim. 1993. Somali reference grammar. Kesington, MD: Dunwoody Press.

Saeed, John Ibrahim. 1999. Somali. Amsterdam/Philadelphia: John Benjamins.

Schadeberg, Thilo. 2003. Derivation. In Derek Nurse \& Gérard Philippson (eds.), The Bantu languages, 71-89. London: Routledge.

Tosco, Mauro. 1994. On case marking in the Ethiopian language area (with special reference to subject marking in East Cuchitic. In Vermondo Brugnatelli (ed.), Sem Cam Iafet, 225-244. Milan: Centro di Studi Camito-Semitici.

Tosco, Mauro. 2012. The unity and diversity of Somali dialectal variants. In Nathan Oyori Ogechi, Jane A. Ngala Oduor \& Peter Iribemwangi (eds.), The harmonization and standardization of Kenyan languages. Orthography and other aspects, 263-280. Cape Town: CASAS.

Zaborski, Andrzej. 1967. Arabic loan-words in Somali: preliminary survey. Folia Orientalia 8. 125-175. 


\section{A Noun entries}

\begin{tabular}{|c|c|c|c|c|}
\hline \# singular & gen & class & plural (gen) & gloss \\
\hline 1 aabbé & $\mathrm{M}$ & 6 & aabbayáal (F) & father \\
\hline 2 ábti & $\mathrm{M}$ & 2 & abtiyó (F), abtiyáal (F) & maternal uncle \\
\hline 3 adéer & $\mathrm{M}$ & 2 & adeerró (F) & paternal uncle \\
\hline 4 áf & $\mathrm{M}$ & 4 & afáf $(\mathrm{M})$, afyáal $(\mathrm{F})$ & tongue \\
\hline 5 albáab & $\mathrm{M}$ & 2 & albaabyó (F), albaabbó (F) & door \\
\hline 6 áqal & $\mathrm{M}$ & 2 & aqalló (F) & home \\
\hline 7 ardéy & $\mathrm{M}$ & 5 & ardeý $(\mathrm{F})$, ardeyáal (F) & (male) student \\
\hline 8 áwr & $\mathrm{M}$ & 5 & aẃr $(\mathrm{F})$ awryáal $(\mathrm{F})$, awrár $(\mathrm{M})$ & camel \\
\hline 9 baabúur & $\mathrm{M}$ & 2 & baabuurró (F), baabuuryáal (F) & truck \\
\hline 10 báhal & $\mathrm{M}$ & 2 & bahalló $(\mathrm{F})$, bahalyáal $(\mathrm{F})$, bahalloóyin $(\mathrm{Ppl})$ & wild animal \\
\hline 11 bálli & $\mathrm{M}$ & 2 & balliyó (F) & small lake \\
\hline 12 baré & $\mathrm{M}$ & 6 & barayáal (F) & teacher \\
\hline 13 bás & $\mathrm{M}$ & 4 & basás $(\mathrm{M})$ & bus \\
\hline 14 béer & $\mathrm{M}$ & 2 & beeryó $(\mathrm{F})$ beeryáal $(\mathrm{F})$ & liver \\
\hline
\end{tabular}




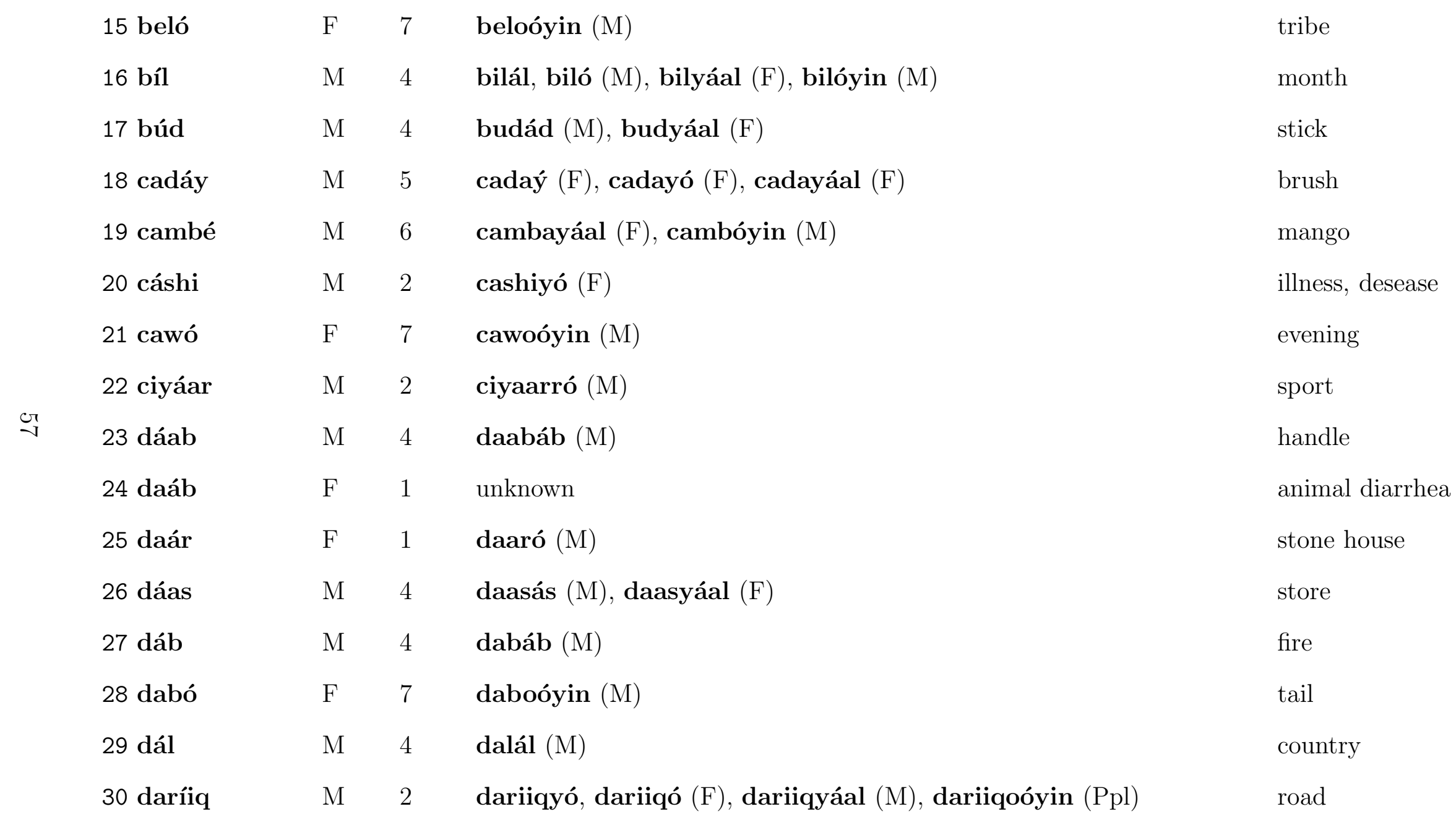




\begin{tabular}{|c|c|c|c|}
\hline 31 dawó & $\mathrm{F}$ & 7 & dawoóyin (M) \\
\hline 32 dayuurád & $\mathrm{F}$ & 1 & dayuuradó (M) \\
\hline 33 dhágax & M & 2 & dhagaxyó $(\mathrm{F})$, dhagaxyáal $(\mathrm{F})$, dhagaxán $(\mathrm{F})$ \\
\hline 34 dhég & $\mathrm{F}$ & 1 & dhegó (M), dhegág (M) \\
\hline 35 dhínac & M & 2 & dhinacyó (F), dhinacyáal (F) \\
\hline 36 dhúl & M & 4 & dhulál (M) \\
\hline 37 díbi & M & 5 & dibí $(\mathrm{F})$, dibiyó $(\mathrm{F})$, dibiyáal $(\mathrm{F})$ \\
\hline 38 doólli & M & 2 & doolliyó $(\mathrm{F})$, doolliyáal $(\mathrm{F})$ \\
\hline 39 dúb & M & 4 & dubáb (M) \\
\hline 40 dúgsi & M & 2 & dugsiyó $(\mathrm{F})$, dugsiyáal $(\mathrm{F})$ \\
\hline 41 dukáan & M & 2 & dukaannó, -nyó, -mó (F), dukaanyáal (F) \\
\hline 42 duráy & M & 2 & durayó (F), durayáal (F) \\
\hline 43 durbáan & M & 2 & durbaannó, durbaanyó (F) \\
\hline 44 éy & M & 5 & eý $(\mathrm{F})$, eyó $(\mathrm{F})$, ey $(\mathrm{y})$ áal $(\mathrm{F})$ \\
\hline 45 fílin & M & 2 & filmó (F) \\
\hline 46 fursád & $\mathrm{F}$ & 1 & fursadó (M) \\
\hline
\end{tabular}

medicine, drug

airplane

stone

ear

side, direction

land, earth

bull

mouse

skin

school

shop

cold, flu

drum

$\operatorname{dog}$

movie

chance 


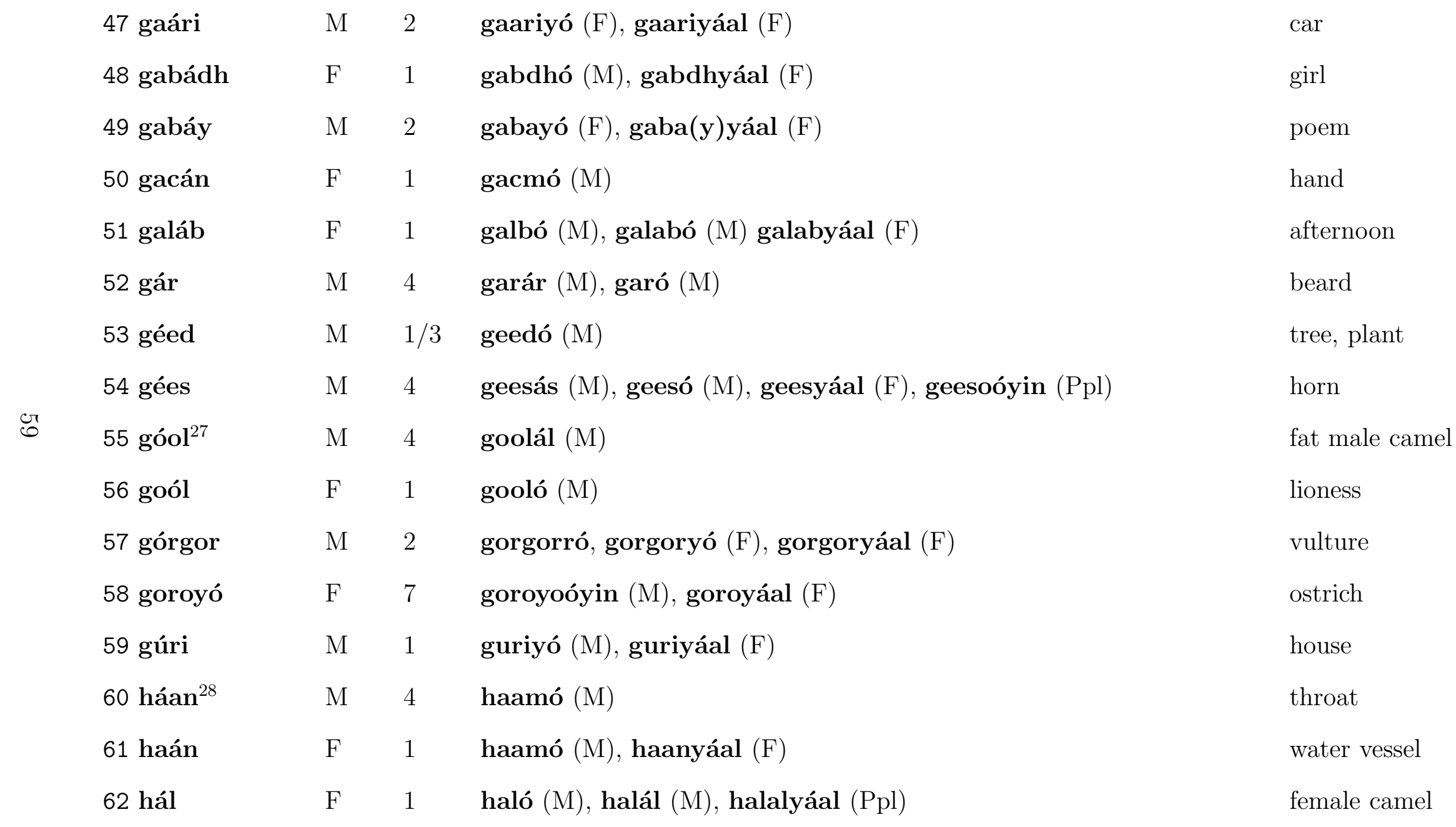




\begin{tabular}{|c|c|c|c|}
\hline 63 heés & $\mathrm{F}$ & 1 & heesó $(\mathrm{M})$, heesás $(\mathrm{F} ?)$, heesoóyin $(\mathrm{Ppl})$ \\
\hline 64 hílib & $\mathrm{M}$ & 3 & hil(i)bó $(\mathrm{M})$, hilibyó $(\mathrm{F})$, hilibyáal $(\mathrm{F})$ \\
\hline 65 hooyó & $\mathrm{F}$ & 7 & hooyoóyin (M), hooyáal (F) \\
\hline 66 hudhéel $^{29}$ & $\mathrm{M}$ & 2 & hudheelló (F), hudheelyáal (F) \\
\hline 67 íl & $\mathrm{F}$ & 1 & iló $(\mathrm{M})$, indhó $(\mathrm{M})$, ilál $(\mathrm{M})$, indhoóyin $(\mathrm{Ppl})$ \\
\hline 68 ílig & $\mathrm{M}$ & 3 & ilkó $(\mathrm{M})$, iligyáal $(\mathrm{F})$, ilkoóyin $(\mathrm{Ppl})$ \\
\hline 69 ínan & $\mathrm{M}$ & 2 & inammó $(\mathrm{F})$, inanyáal $(\mathrm{F})$, inammayáal $(\mathrm{Ppl})$ \\
\hline 70 inán ${ }^{30}$ & $\mathrm{~F}$ & 1 & unknown \\
\hline 71 jaamacád & $\mathrm{F}$ & 1 & jaamacadó (M) \\
\hline 72 jamhuuriyád & $\mathrm{F}$ & 1 & jamhuuriyadó (M) \\
\hline 73 jamciyád & $\mathrm{F}$ & 1 & jamciyadó (M) \\
\hline 74 jílib & $\mathrm{M}$ & 3 & jilbó $(M)$, jilbyó $(F ?)$ \\
\hline 75 jínni & $\mathrm{M}$ & 2 & jinniyó $(F)$, jinní $(F)$, jinniyáal $(F)$ \\
\hline 76 kaalmó & $\mathrm{F}$ & 7 & kaalmoóyin (M) \\
\hline 77 káb & $\mathrm{F}$ & 1 & kabó (M), kabáb (M) \\
\hline 78 kallúun 31 & $\mathrm{M}$ & 2 & kallumó, kallunó (F), kallunyáal (F) \\
\hline
\end{tabular}

song

meat

mother

hotel

eye

tooth

boy

girl

university

republic

league, union

knee

Jinn

help

shoe

fish (coll.) 


\begin{tabular}{|c|c|c|c|c|}
\hline 79 khudrád ${ }^{32}$ & $\mathrm{~F}$ & 1 & khudradó $(\mathrm{M})$, khudradyáal $(\mathrm{F})$ & fruit (coll.) \\
\hline 80 kóob & M & 4 & koobáb (M), koobyáal (F), kooboóyin (M) & cup \\
\hline 81 kuráy & M & 2 & kurayó (F), kuray(y)áal (F) & lad, boy \\
\hline 82 kúrsi & M & 2 & kursiyó $(\mathrm{F})$, kursiyáal $(\mathrm{F})$, kuraasí, kuraás $(\mathrm{F})$, kuraasoóyin $(\mathrm{M})$ & chair \\
\hline 83 libáax & M & 2 & libaaxyó $(\mathrm{F})$, libaaxyáal $(\mathrm{F})$, libaáx $(\mathrm{F})$ & lyon \\
\hline 84 lúg & $\mathrm{F}$ & 1 & lugó $(\mathrm{M})$, lugág $(\mathrm{M})$ & foot \\
\hline 85 maalín & $\mathrm{F} / \mathrm{M}$ & $1 / 2$ & maalimmó $(\mathrm{F})$, maalmyáal $(\mathrm{F}), \operatorname{maal}(\mathrm{i})$ mó $(\mathrm{M})$, maalinyó $(\mathrm{F} ?)$ & day \\
\hline 86 macállin $^{33}$ & M & 2 & macallimmó $(\mathrm{F})$, macallimyáal $(\mathrm{F})$, macallinyó $(\mathrm{F})$ & teacher \\
\hline 87 mádax & M & $2 / 5$ & madaxyó $(\mathrm{F})$, madaxyáal $(\mathrm{F})$, madáx $(\mathrm{F})$ & head \\
\hline 88 magaaló & $\mathrm{F}$ & 7 & magaaloóyin $(\mathrm{M})$, magaaloyáal $(\mathrm{F})$ & city \\
\hline 89 mágac & $\mathrm{M}$ & 2 & magacyó (F), magacyáal $(\mathrm{F})$, magacoóyin $(\mathrm{M})$ & noun, name \\
\hline 90 makhaayád & $\mathrm{F}$ & 1 & makhaayadó (M), makhaayadyáal (F) & restaurant \\
\hline 91 maqaalín & $\mathrm{F}$ & 1 & maqaalimó $(\mathrm{M})$ & fishing hook \\
\hline 92 marqaáti & M & 2 & marqaatiyó $(\mathrm{F})$, marqaatiyáal $(\mathrm{F})$ & witness \\
\hline 93 masaájid & $\mathrm{M}$ & 2 & masaajidyó $(\mathrm{F})$, masaajiddó $(\mathrm{F})$ & mosque \\
\hline 94 míis & $\mathrm{M}$ & 3 & miisás, miisó $(\mathrm{M})$, miisyáal $(\mathrm{F})$, miisasyáal $(\mathrm{Ppl})$ & table \\
\hline
\end{tabular}




\begin{tabular}{|c|c|c|c|c|}
\hline 95 mindí & $\mathrm{F}$ & 1 & mindiyó (M), mindiyáal (F) & knife \\
\hline 96 móos & $\mathrm{M}$ & 4 & moosás (M) & banana \\
\hline 97 naág & $\mathrm{F}$ & 1 & naagó (M), naagayáal (Ppl) & woman \\
\hline 98 néef & $\mathrm{M}$ & 4 & neefáf $(\mathrm{M})$, neefyáal $(\mathrm{F})$ & pet \\
\hline 99 neéf & $\mathrm{F}$ & 1 & neefó $(\mathrm{F})$ & breath \\
\hline 100 nín & $\mathrm{M}$ & 4 & nimán $(\mathrm{M})$, nimó $(\mathrm{M})$, nimyáal $(\mathrm{F})$ & man \\
\hline 101 óon & $\mathrm{M}$ & 2 & unknown & thirst \\
\hline 102 oón $^{34}$ & $\mathrm{~F}$ & 1 & unknown & food \\
\hline 103 ordinatéer & $\mathrm{M}$ & 2 & ordinateerró $(F)$, ordinateeryó (F) & computer \\
\hline 104 órgi & $\mathrm{M}$ & 2 & orgiyó $(\mathrm{F})$, orgiyáal $(\mathrm{F})$, orgí $(\mathrm{F})$ & male goat \\
\hline 105 qáan $^{35}$ & $\mathrm{M}$ & 2 & qaanyáal (F) & young camel(s) \\
\hline 106 qaán & $\mathrm{F}$ & 1 & qaamó, qaanó (M) & debt \\
\hline 107 qálin & M & 2 & qalimmó, qalinnó (F), qalimyáal, qalinyáal (F) & pen \\
\hline 108 qasacád ${ }^{36}$ & $\mathrm{~F}$ & 1 & qasacadó (M) & can, box \\
\hline 109 qáyb & $\mathrm{F}$ & 1 & qaybó (M), qaybyó (F?), qaybyáal (F), qayboóyin (Ppl) & part, share \\
\hline 110 qódob & M & 3 & qod(o)bó (M), qodobyó (F), qodobyáal (F) & article \\
\hline
\end{tabular}




\begin{tabular}{|c|c|c|c|c|}
\hline 111 qól & $\mathrm{M}$ & 4 & qolál (M), qolyáal (F) & room \\
\hline 112 qóys & $\mathrm{M}$ & 4 & qoysás $(\mathrm{M})$, qoysyáal (F), qoysyó (F?) & family \\
\hline 113 qúrac & $\mathrm{M}$ & 2 & quracyó (F), quracyáal (F) & acacia \\
\hline 114 ráh & $\mathrm{M}$ & 2 & rahyó, rahyáal $(\mathrm{F})$; raháh, rahó $(\mathrm{M})$ & frog \\
\hline 115 rí & $\mathrm{F}$ & 1 & riyó (M) & female goat \\
\hline 116 róob & $\mathrm{M}$ & 4 & roobáb $(\mathrm{M})$ & rain \\
\hline 117 roóti & $\mathrm{M}$ & 2 & rootiyáal $(\mathrm{F})$ & bread \\
\hline 118 sáab & $\mathrm{M}$ & 4 & saabáb (M), saabó (M) & flask \\
\hline 119 sánad & $\mathrm{M}$ & 2 & sanaddó (F), sanadyáal (F) & year \\
\hline 120 saaxíib $^{37}$ & $\mathrm{M}$ & 2 & saaxiibyó, saaxiibbó (F), saaxiibyáal (F) & friend \\
\hline 121 sabáb & $\mathrm{F}$ & 1 & sababó (M), sababyó (F?) & cause, excuse \\
\hline 122 sác & $\mathrm{M}$ & 2 & sacyó $(\mathrm{F})$, sacyáal $(\mathrm{F})$ & cow \\
\hline 123 sálli & $\mathrm{M}$ & 2 & salliyó (F), salliyáal (F) & prayer mat \\
\hline 124 sámbab & $\mathrm{M}$ & 2 & sambabbó, sambabyó (F), sambabyáal (F) & lung \\
\hline 125 sán & $\mathrm{M}$ & 4 & sanán $(M)$, sanyó $(F)$, sanyáal $(F)$ & nose \\
\hline 126 shabéel & $\mathrm{M}$ & 2 & shabeelló, shabeelyó (F), shabeelyáal (F), shabeellayáal (Ppl) & leopard \\
\hline
\end{tabular}




\begin{tabular}{|c|c|c|c|c|}
\hline 127 shaqó & $\mathrm{F}$ & 7 & shaqoóyin $(\mathrm{M})$, shaqayáal $(\mathrm{F})$ & work \\
\hline 128 sheekó & $\mathrm{F}$ & 7 & sheekoóyin (M), sheekayáal (F), sheeka-sheekó (reduplicated pl.) & tale, story \\
\hline 129 shímbir & $\mathrm{M}$ & 2 & shimbirró $(\mathrm{M})$, shimbiryáal $(\mathrm{F})$ & bird \\
\hline 130 soomaáli & $\mathrm{M}$ & 5 & soomaalí $(\mathrm{F})$, soomaaliyáal $(\mathrm{F})$ & Somali \\
\hline 131 súbax & $\mathrm{M}$ & 2 & $\operatorname{subax}(y) o ́(F)$, subaxyáal $(F)$ & morning \\
\hline 132 suldáan & M & 2 & suldaannó $(\mathrm{F})$ & sultan \\
\hline 133 súuq & M & 2 & suqyó $(\mathrm{F})$, suuqyáal $(\mathrm{F})$, suuqáq $(\mathrm{M})$ & market \\
\hline 134 tágsi & M & 2 & tagsiyó $(\mathrm{F})$, tagsiyáal $(\mathrm{F})$, takaasí $(\mathrm{F})$ & taxi cab \\
\hline 135 terráin $^{38}$ & M & 2 & terranyó, -nnó $(\mathrm{F})$, terranyáal $(\mathrm{F})$ & sport field \\
\hline 136 toddobáad & $\mathrm{M}$ & 2 & toddobaadyó, -ddó $(\mathrm{F})$, toddobaadyáal $(\mathrm{F})$ & week \\
\hline 137 tuké & M & 6 & tukayáal (F) & crow, raven \\
\hline 138 ugáx $^{39}$ & $\mathrm{~F}$ & 1 & ugaxyó $(\mathrm{F})$, ugaxyáal $(\mathrm{F})$ & egg \\
\hline 139 wáddan & $\mathrm{M}$ & 2 & waddannó, waddammó (F) & country, state \\
\hline 140 waddó & $\mathrm{F}$ & 7 & waddoóyin (M) & road \\
\hline 141 waláal & $\mathrm{M}$ & 2 & walaalyó, -lló $(\mathrm{F})$, walaalyáal $(\mathrm{F})$, walaaloóyin $(\mathrm{Ppl})$ & brother \\
\hline 142 wán & $\mathrm{M}$ & 4 & wanán (M) & male sheep \\
\hline
\end{tabular}




$\begin{array}{lllll}143 \text { wár } & \mathrm{M} & 4 & \text { warár }(\mathrm{M}) & \text { news } \\ 144 \text { waraabé }^{40} & \mathrm{M} & 6 & \text { waraabayáal }(\mathrm{F}) \text {, waraaboóyin }(\mathrm{M}) & \text { hyena } \\ 145 \text { waranlé }^{41} & \mathrm{M} & 6 & \text { waranlayáal }(\mathrm{F}) \text {, waranloóyin }(\mathrm{M}) & \text { ppearman } \\ 146 \text { warqád } & \mathrm{F} & 1 & \text { warqadó }(\mathrm{M}) & \text { thing } \\ 147 \text { wáx } & \mathrm{M} & 2 & \text { waxyaálo, -yaábo }(\mathrm{M}) \text {; waxyó, waxyáal }(\mathrm{F}) & \text { kid } \\ 148 \text { waxár } & \mathrm{F} & 1 & \text { waxaró }(\mathrm{M}) & \text { boy } \\ 149 \text { wíil } & \mathrm{M} & 4 & \text { wiilál }(\mathrm{M}), \text { wiilyó }(\mathrm{F}) \text {, wiilyáal }(\mathrm{F}) & \text { rope }\end{array}$




\footnotetext{
${ }^{27}$ Four informants claim that the actual form is géel. According to Puglielli \& Mansuur (2012), géel (M, 3) and góol are two distinct words: the former is a collective noun indicating a group of camels, whereas the latter is a fat male camel.

${ }^{28}$ Only two informants know this noun, but neither of them knows Som plural form haanán (Puglielli \& Mansuur 2012:378).

${ }^{29}$ Two additional forms exist: hudheelyó (a variant of hudheelló) and hudheelál. The latter is intriguing: why a non-monosyllabic M noun should be pluralized via reduplication (cf. class 4)?

${ }^{30}$ Suppletive plural is used: habló. Som regular plural *inamó is ungrammatical for my informants.

${ }^{31}$ According to Puglielli \& Mansuur (2012:496), kallúun is an M collective noun, thus it has no plural form; despite this fact, all the informants pluralize it. In addition, one informant proposes a plural of plural construction: kalluunayáal $/ \mathrm{kallun}+\mathrm{o}+\mathrm{yaal} /$.

${ }^{32}$ khudrád is an F collective noun and, indeed, some informants don't accept any plural forms. Other informants, in turn, do accept a plural form: either khudradó or khudradyáal. The corpus contains an additional collective noun: kameecó 'mosquitoes' (F, 7). In this case, none of the informants accepts a plural form.

${ }^{33}$ Arabic plural is also possible: macallimín, macallimán.

${ }^{34}$ Only one informant knows óon (M), whereas none of them knows oón (F). According to Puglielli \& Mansuur (2012:651), both nouns are collective nouns, thus plural form is not expected.

${ }^{35}$ Qáan (M) is a collective noun. No informant accepts a regular plural form, as expected. The plural qaanyáal is proposed only by one informant.

${ }^{36}$ Three informants propose the plural forms qasacyó $(\mathrm{F})$ and qasacyáal $(\mathrm{F})$. These forms are built on singular qásac (M) which, according to Puglielli \& Mansuur (2012:677) is a synonym.

${ }^{37}$ One informant proposed the Ar. broken plural asxaáb $(\mathrm{F})$.

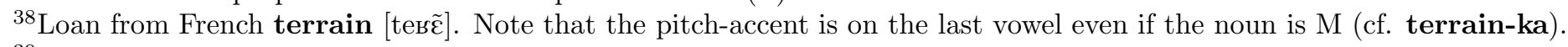

${ }^{39}$ None of the informants knows the irregular plural form ugaxáan $(\mathrm{F})$ and the majority of them claims that there is no plural for this noun.

${ }^{40}$ One informant proposes the following plural form: waraabeyó (M?).

${ }^{41}$ One informant proposes the following plural form: waranleyó (M?). This is, together with \#144, the only case of the suffix -o used to pluralize a noun belonging to group 6.
} 